\title{
FACTORS DOMINATING ADHESION OF NaCl ONTO POTATO CHIPS
}

\author{
A Thesis \\ Presented in Partial Fulfillment of the Requirements for \\ The Degree Masters of Science in the \\ Graduate School of The Ohio State University
}

By

Vinodini Emmanuela Buck, B.S.

$* * * * *$

The Ohio State University

2007

Master's Examination Committee

Dr. Sheryl A. Barringer, Adviser

Dr. VM Balasubramaniam

Dr. David B. Min

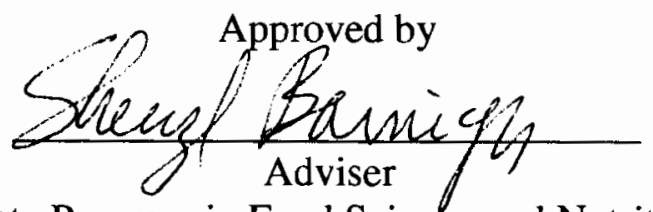

Graduate Program in Food Science and Nutrition 


\begin{abstract}
In this study the factors examined were surface oil content, chip temperature, time between frying and coating, oil composition, salt particle size, salt crystal shape, and electrostatic coating. Three different surface oil content (SOC) potato chips, high, low and no, were produced. Oils used were soybean, olive, corn, peanut and coconut. After frying, chips were coated immediately, after 1 day, and after 1 month. $\mathrm{NaCl}$ crystals of five different particle sizes $(24.7,123,259,291,388 \mu \mathrm{m})$ were coated both electrostatically (corona charging) and nonelectrostatically. Adhesion of cubic, dendritic, and flake crystals were examined. A vibrating feeder was used to test adhesion of salt. Fried chips were heated to test the effect of chip temperature. Chips with high SOC had the highest adhesion of salt, making SOC the most important factor. Increasing chip temperature increased SOC and adhesion. Increasing time between frying and coating reduced adhesion for low SOC level chips, but did not affect high and no SOC chips. Changing oil composition did not affect adhesion. Increasing salt size decreased adhesion. Salt size effect was greater in chips with lower SOC. For chips with low and no SOC, cubic crystals gave the best adhesion followed by small flake crystals then dendritic crystals. For high and low SOC chips electrostatic coating did not change adhesion of small size crystals but decreased adhesion of large salts. For no SOC chips electrostatic coating improved adhesion for small salt sizes but did not affect adhesion of large crystals.
\end{abstract}




\section{DEDICATION}

Dedicated to my grandparents: The Rev. Balraj and Florence Milton 


\section{ACKNOWLEDGMENTS}

I am grateful to God for His many blessings and grace.

I thank Dr. Sheryl Barringer for her encouragement, knowledge and guidance in the completion of this degree.

I thank my parents and brother for their prayers, love and encouragement.

I thank all my professors and especially my committee members, Dr. Sheryl Barringer, Dr. VM (Bala) Balasubramaniam and Dr. David Min, in the food science department for the gift of knowledge and understanding. It was an honor to be their student.

I thank my friends and fellow office and lab mates in the food science department for their friendship and support. The many good times we have shared will always be treasured. 


\section{VITA}

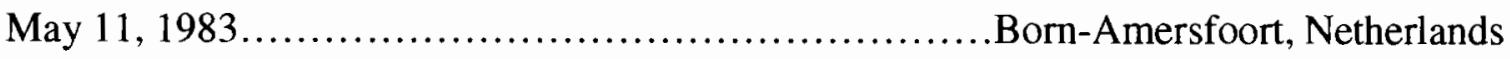

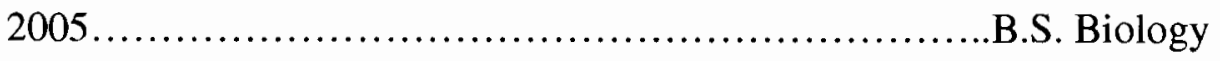

The Ohio State University

2005-present.

Graduate Research and

Teaching Associate,

The Ohio State University

Fields of Study:

Major Field: Food Science and Technology 


\section{TABLE OF CONTENTS}

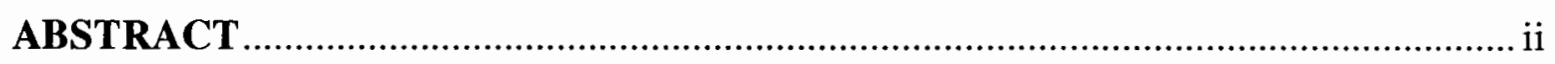

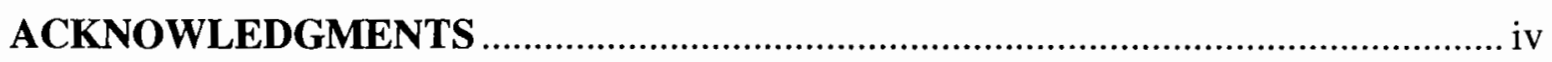

VITA

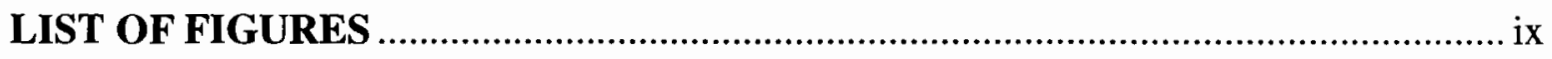

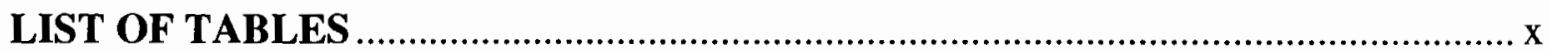

CHAPTERS

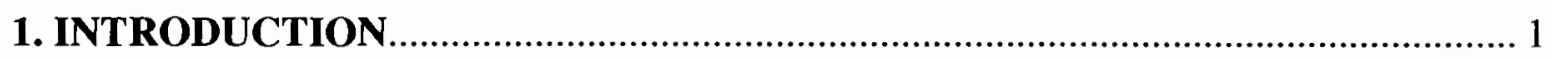

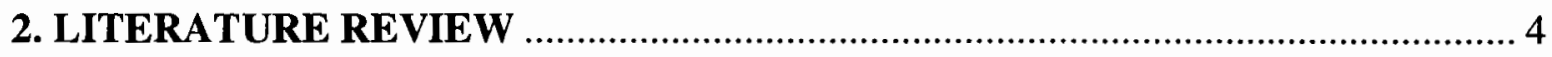

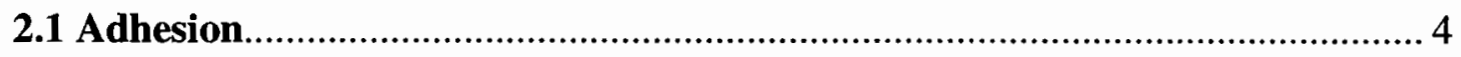

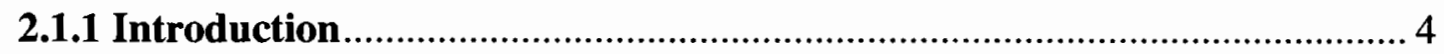

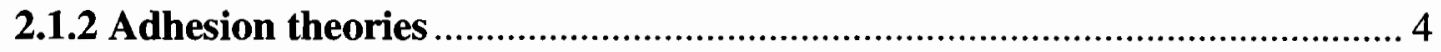

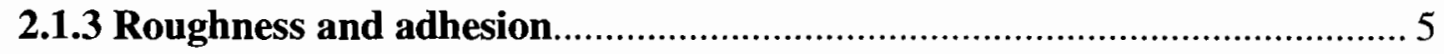

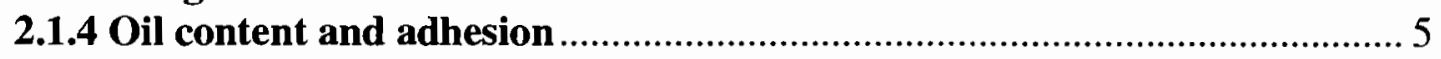

2.1.5 Particle size affect on adhesion and transfer efficiency............................. 6

2.1.6 Salt shape and adhesion............................................................................. 7

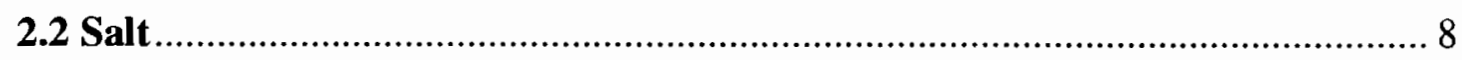

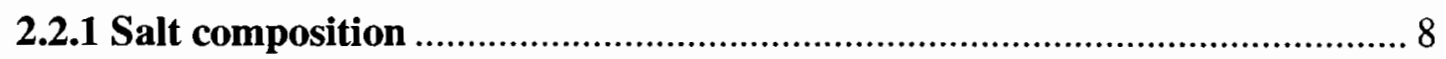

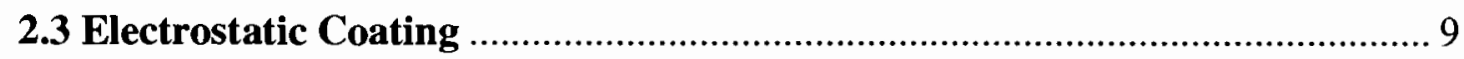

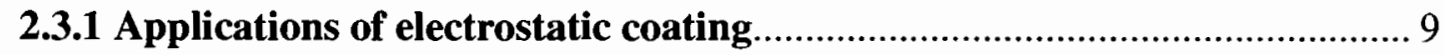

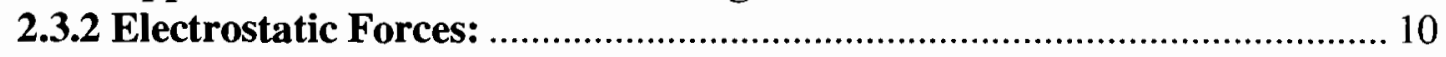

2.3.3 Particle size and electrostatic coating …............................................ 10

2.3.4 Resistivity and electrostatic coating ..................................................... 11

2.3.5 Positive vs. negative electrostatic coating ….............................................. 12 


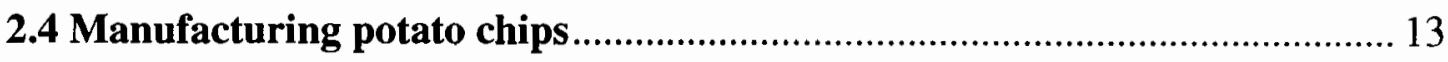

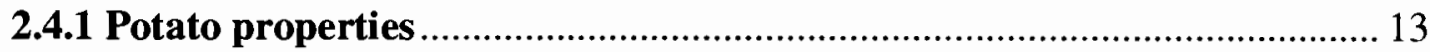

2.4.2 Potato pre manufacturing and post manufacturing protection: ............... 13

2.4.3 Potato chip properties........................................................................... 14

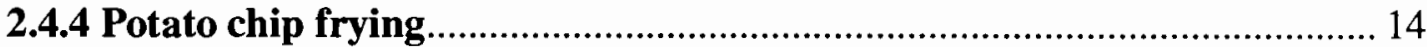

2.4.5 Reducing browning in potato products: .............................................. 14

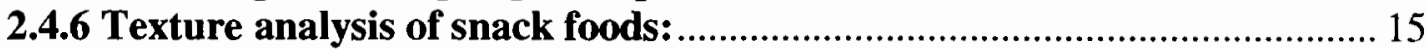

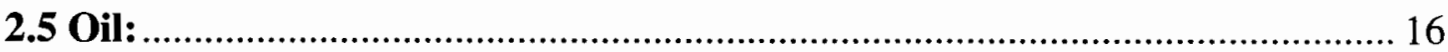

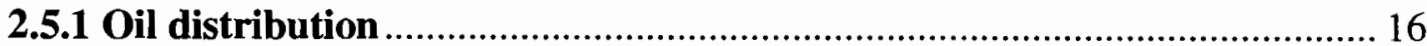

2.5.2 Time and temperature and surface oil content .................................... 16

2.5.3 Measuring total oil content .................................................................... 17

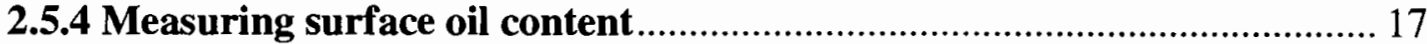

2.5.5 Reducing oil absorption in potato chips: ............................................. 19

2.5.6 Reducing oil absorption in french fries: .................................................. 20

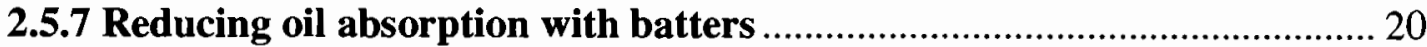

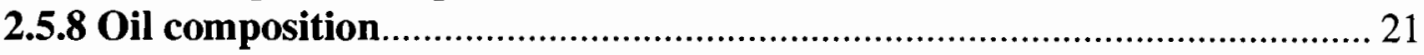

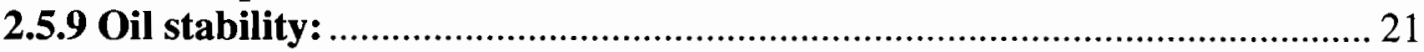

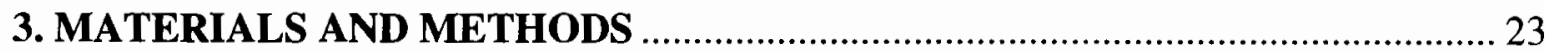

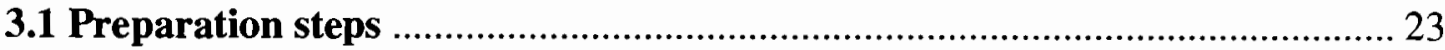

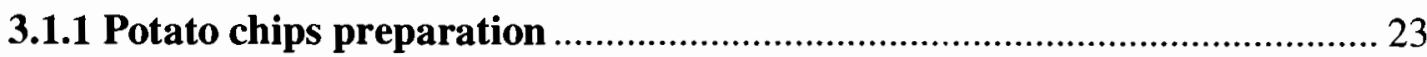

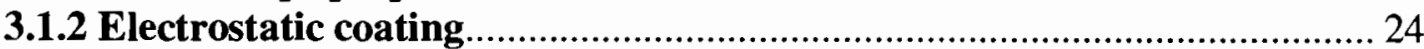

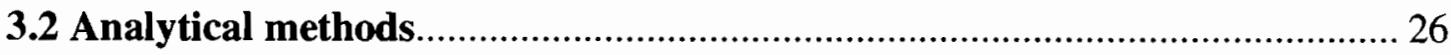

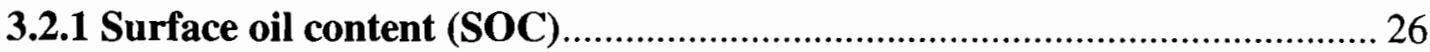

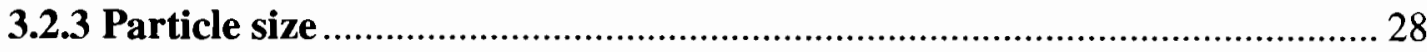

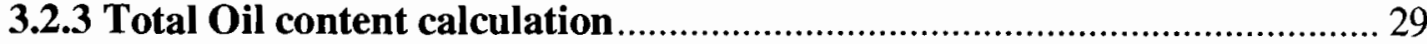

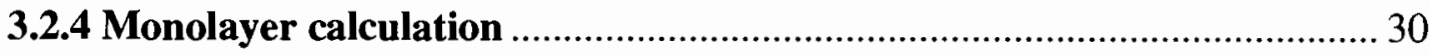

3.2.5 Vibration method for adhesion measurement........................................... 31 


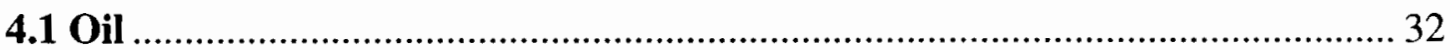

4.1.1 Time between frying and coating ………................................................. 32

4.1.2 Chip temperature effect on adhesion ......................................................... 34

4.1.3 Oil composition effect on adhesion ............................................................ 37

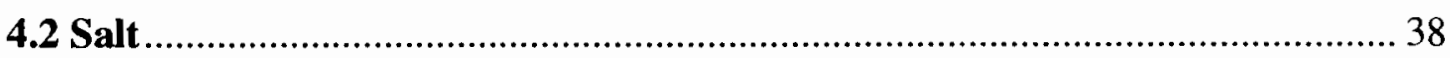

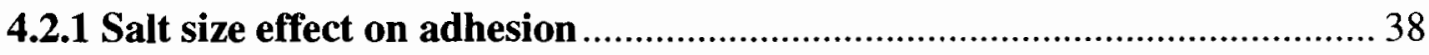

4.2.2 Salt shape effect on adhesion ................................................................... 40

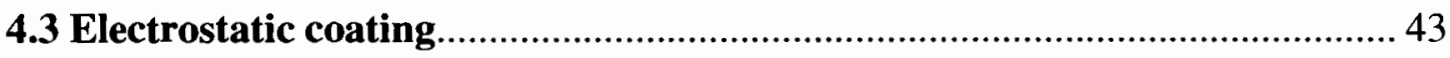

4.3.1 Electrostatic coating and adhesion ............................................................ 43

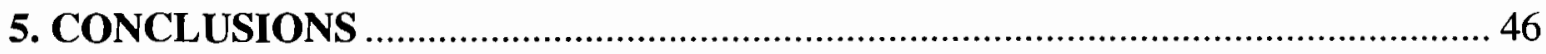

REFERENCES

APPENDIX A ADHESION DATA AND FIGURES ……......................................... 54 


\section{LIST OF FIGURES}

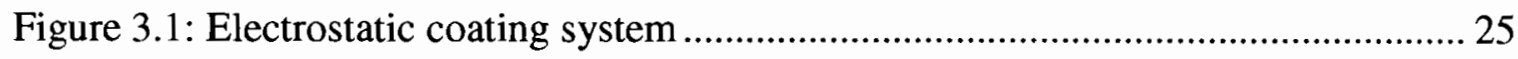

Figure 3.2: Surface oil extraction aluminum chips ........................................................ 27

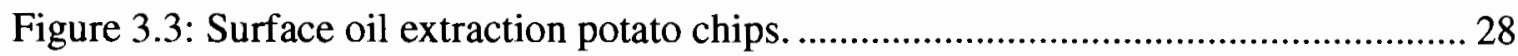

Figure 3.4: Adhesion measurement using a feeder ........................................................ 31

Figure 4.1: Effect of delaying coating on adhesion........................................................ 34

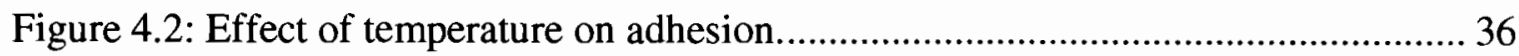

Figure 4.3: Relationship between chip temperature and surface oil content................... 37

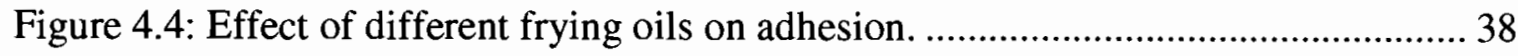

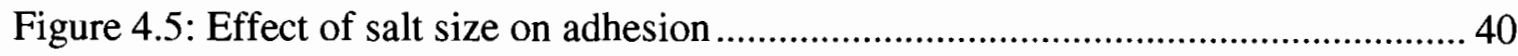

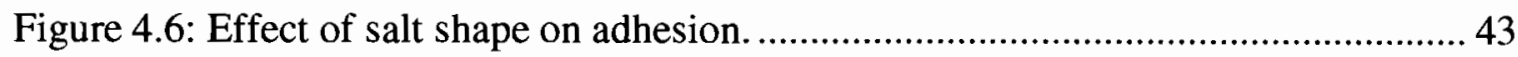

Figure 4.7: Electrostatic and Nonelectrostatic adhesion ............................................ 45

Figure A.1: Surface oil content measurement of chips after 1 day......................58 


\section{LIST OF TABLES}

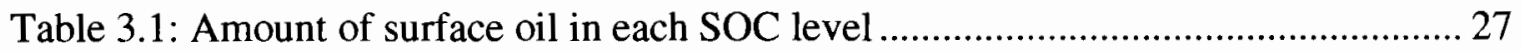

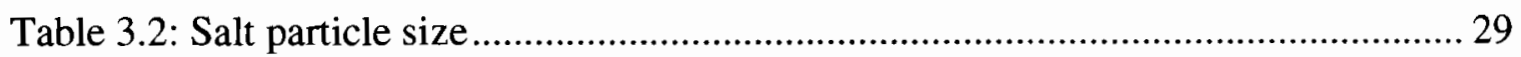

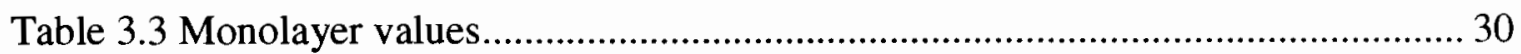

Table A.1: Salt crystal shapes and their attributes ........................................................5

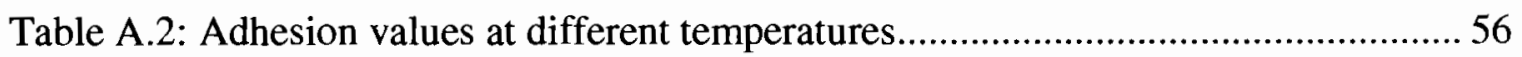

Table A.3: Surface oil content measurements at different temperatures......................... 56

Table A.4: Comparison of measured surface oil and calculated surface oil....................55

Table A.5: Adhesion values after delaying and coating ….......................................... 57

Table A.6: Effect of oil composition on adhesion ........................................................ 59

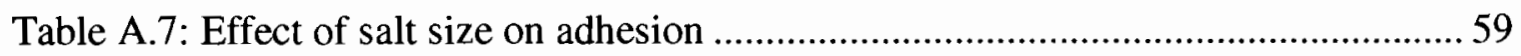

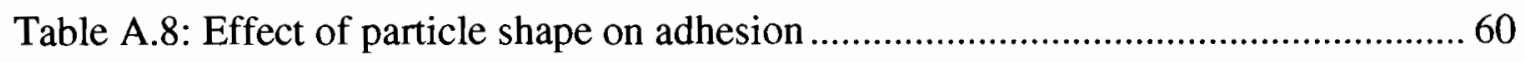

Table A.9: Effect of electrostatic coating compared with nonelectrostatic coating.........61 61 


\section{CHAPTER 1}

\section{INTRODUCTION}

Potato chip sales in the United States exceed $\$ 6$ billion (Berry 2003). In order to gain consumer loyalty in a competitive snack food market, companies need to be able to consistently produce well coated products. In the food industry adhesion of seasoning to food surfaces is important to understand to improve the process of coating various snack products, as well as reduce cleaning costs associated with adhesion of coatings to food equipment.

Many snack foods are fried and powder coated. The two most common ways to apply seasoning are tumble drum and conveyor belt. Potato chips contain about $35 \%$ oil (Pedreschi and Moyano 2005a). In order for the seasoning to adhere to the potato chips, most manufacturers coat the chips immediately after frying or apply the oil and seasoning simultaneously (Berry 2003). Increasing surface oil content increases adhesion (Enggalhardjo and Narsimhan 2005). Oil is viscous, and holds particles through liquid bridges (Takenaka and others 2006). Increasing oil content leads to more efficient coating, regardless of the size and shape of salt crystals (Miller and Barringer 2002). 
After chips are removed from the fryer, surface oil content decreases rapidly as oil is absorbed inside the chip (Moreira and others 1997). Immediately coating fried chips will give high adhesion of the seasoning. Allowing the chips to cool after frying promotes surface oil absorption inside the chip weakening capillary forces and decreasing adhesion (Moreira and others 1997).

Oil composition is an important factor in oil absorption, and quality of potato chips (Melton and others 1993). Few studies have examined differences in adhesion due to differences in frying oils. Enggalhardjo and Narsimhan (2005) found that tortilla chips sprayed with olive oil have a higher adhesive force holding the seasoning, preventing removal, compared to chips sprayed with soybean oil. They attributed this difference in adhesion force to differences in viscosity between the two oils.

Smaller particle size enhances adherence (Niman 2000). Compared to large salt crystals, small salt crystals often show strong adhesion to surfaces regardless of surface oil content and roughness of the surface (Bowling 1988). Small particles also coat more efficiently than large particle in both electrostatic and nonelectrostatic coating (Miller and Barringer 2002). If the salt size is smaller than the pore size of the surface more mechanical interlocking occurs. Small salt crystals have more surface area than mass and as a result van der Waals forces per unit mass are stronger (Bowling 1988).

Besides salt particle size, particle shape is also an important adhesion factor. Miller and Barringer (2002) found that flake 1a coated more efficiently than cube and 
dendritic shapes. Niman (2000) found that dendritic crystals give adhesion results similar to flake $1 \mathrm{ab}$ and flake 2 crystals. When comparing crystals larger than $300 \mu \mathrm{m}$, flake $\mathrm{lb}$ gives higher adherence than flake 2 and cubic shapes (Niman 2000).

Electrostatic coating has often been used in the paint industry to control the amount of coating applied (Cross 1981). Electrostatic coating improves adhesion of powders on food with low oil content (Halim and Barringer 2007). Electrostatically charged food powders give strong adhesion to aluminum and graham crackers (Sumawi and Barringer 2005; Mayr and Barringer 2006). In electrostatic corona charging, powders pick up charge as they pass through the corona zone and are attracted to the nearest grounded object where an opposite image charge is created (Halim and Barringer 2007). Small particles have a higher charge to mass ratio compared to large particles and thus show greater improvement in adhesion and transfer efficiency with electrostatic coating (Mayr and Barringer 2006).

The objective of this study was to determine which factors such as surface oil content, time between frying and coating, chip temperature, oil composition, salt particle size, salt crystal shape, and the use of electrostatics dominate adhesion of salt onto potato chips. 


\section{CHAPTER 2}

\section{LITERATURE REVIEW}

\subsection{Adhesion}

\subsubsection{Introduction}

Adhesion is quantified as the work done in separating two surfaces that are in contact with each other (Mittal 1977). In the food industry adhesion of seasoning to surfaces is important to understand to effectively coat products with minimum wastage of seasoning as well as reduce cleaning cost associated with adhesion of coatings to food equipment. In the dairy industry, major problems occur due to adhesion of solids such as protein and fat from hot milk diminishing heat transfer efficiency (Michalski and others 1997). The eventual strength of an adhesive bond is dependent upon factors such as surface roughness, size and shape of surfaces, the mechanical properties of the particles, surface contact areas and the state of cleanliness of the interacting bodies (Lam and Newton 1991).

\subsubsection{Adhesion theories}

Theories of adhesion include: mechanical interlocking, van der Waals forces, electrostatic forces and capillary forces (Michalski and others 1997). Mechanical interlocking is the oldest adhesion theory that states materials adhere because of locking 
through their pores and asperities (Michalski and others 1997). Most forces dominating adhesion between solid surfaces are van der Waals and electrostatic forces. Van der Waals forces of attraction exist between polar molecules that are close together (Brown and others 2000). Electrostatic forces exist between two oppositely charged particles. When solid liquid surfaces interact capillary forces also play a role in adhesion (Enggalhardjo and Narsimhan 2005). Capillary forces occur when intermolecular forces between the liquid and solid are stronger than the intermolecular forces within the liquid. High relative humidity causes an increase in capillary forces (Bowling 1988; Michalski and others 1997).

\subsubsection{Roughness and adhesion}

Various studies have found two opposing results between adhesion and roughness. Food surface deformation increases surface roughness (Bowling 1988). Increasing surface roughness increases particle contact area and creates strong van der Waals forces (Bowling 1988; Michalski and others 1997). However, smooth surfaces reduce the distance of particle separation, causing the bulk of the particles to be in much closer contact with the surface increasing adhesion (Lam and Newton 1991).

\subsubsection{Oil content and adhesion}

Higher total oil usually equates to higher surface oil (Takenaka and others 2006). In a comparison of sesame seeds with surface oil content of $0.77 \%$ and $0.43 \%$, the seeds with the higher surface oil content had higher adhesion to other seeds (Takenaka and 
others 2006). Oil on top of solid surfaces produces a wet system in which capillary forces dominate over other forces such as van der Waals and electrostatics (Bowling 1988). In capillary condensation a meniscus is formed between the wet and solid surface due to surface tension which reduces the pressure of the liquid causing an attractive force (Ranade 1987). Miller and Barringer (2002) found that for salts of all sizes and shapes, increasing the percent of oil on the substrate from $1 \%$ to $3 \%$, results in more efficient coating. Enggalhardjo and Narsimhan (2005) describe an aerodynamic method for measuring adhesion of seasoning onto tortilla chips using a wind tunnel procedure. In this method by increasing air velocity a higher amount of cheese seasoning is lost from the chips. For tortilla chips with $28 \%$ oil compared to tortilla chips with $24 \%$ oil, a higher air velocity is required to remove the seasoning (Enggalhardjo and Narsimhan 2005).

\subsubsection{Particle size affect on adhesion and transfer efficiency}

$\mathrm{NaCl}$ crystal size is an important factor dominating adhesion of seasoning to food surfaces. Many studies have found that as particle size decreases adhesion increases (Niman 2000; Sumawi and Barringer 2005). Van der Waals forces predominate over electrostatic forces for particles smaller than 50 micrometers (Bowling 1988). Total adhesion force on a particle decreases approximately linearly as a function of the diameter of a particle (Bowling 1988). Smaller particles have more surface area than mass so there is more surface area for interaction (Miller and Barringer 2002). If the salt crystal size is smaller than the pore size of the surface, more mechanical interlocking 
takes place. Enggalhardjo and Narsimhan (2005) found that for large particles a greater adhesion force is required to remove seasoning from tortilla chips. Sucrose particles smaller than $100 \mu \mathrm{m}$ have higher adhesion to saltine crackers, than particles larger than $100 \mu \mathrm{m}$ (Halim and Barringer 2007). Adhesion of sucrose particles to graham crackers increases when particle size increases from 13 to $140 \mu \mathrm{m}$ as larger particles have more contact points for adhesion (Mayr and Barringer 2006). Biehl and Barringer (2004) found that in a conveyor system transfer efficiency increases with increasing particle size going from 50 to $200 \mu \mathrm{m}$.

Studies have also found that small particles coat more efficiently than large particle for both electrostatic and nonelectrostatic coating (Miller and Barringer 2002). In electrostatic coating, small particles obtain greater charge to mass than large particles. A higher charge to mass ratio results in higher electrostatic adhesion (Ricks and Barringer 2002; Mayr and Barringer 2006).

\subsubsection{Salt shape and adhesion}

Crystal configuration is a very important characteristic to consider in deciding which type of salt to use as topping. Each crystal configuration has different physical attributes such as adhesion strength (Niman 2000). Dendritic salt is produced in vacuum pans from chemically purified brine. Dendritic crystals are porous, star shaped modified cubes with high specific surface area and should give adhesion similar to flake crystals (Morton 1997). Dendritic crystals which are about $200 \mu \mathrm{m}$ in size had similar adhesion to 
compacted flake and Alberger flake crystals of approximately the same size (Niman 2000). Flake salt is produced by compacting vacuum salt crystals into flat, smooth surfaced, rectangular aggregates. Compacted flake salt has low bulk density and increased surface area (Niman 2000). Cubic salt is produced by mechanical evaporation of brine in reduced pressure (Niman 2000). This makes the particles less susceptible to attrition (Morton 2004). Cargill produces Alberger flake crystals under a patented process which involves mechanical evaporation to produce irregular crystals with stair step sides so it appears like a quadrilateral pyramid (Kuntz 1994). Irregular shapes can have high adhesion due to liquid filling in gaps creating liquid bridges for better adhesion (Kendall and Stainton 2001). Niman (2002) found for crystals 300 to $1000 \mu \mathrm{m}$ in size, Alberger flake crystals give higher adherence than compacted flake and cubic crystals. For crystals larger than $1000 \mu \mathrm{m}$ compacted flake crystals give higher adhesion than Alberger flake crystals.

\subsection{Salt}

\subsubsection{Salt composition}

Salts are ionic compounds composed of cations such as sodium and anions such as chloride. Salt comes from underground deposits and from solar evaporation of saline sea water (Kuntz 1994). Vacuum crystallization of brine produces salt intended for use on foods. In vacuum crystallization a concentric or cubic crystal is formed. A porous structure can be attained by adding additives such as sodium ferrocyanide or altering the 
process of crystallization (Strietelmeier 1988). Salt purity is an important property because salts contain trace metals such as magnesium which not only are harmful for consumption, but also promote oxidation and form soaps by reacting with fats and oil creating off flavors (Kuntz 1994). Salts are also prone to water absorption which produces caking problems (Kuntz 1994). Many salts contain anti-caking agents such as yellow prussicate of soda (sodium ferrocyanide) and tricalcium phosphate (Morton 1997).

\subsection{Electrostatic Coating}

\subsubsection{Applications of electrostatic coating}

Electrostatic coating was first introduced to the painting industry in the 1960 s (Cross 1981). In electrostatic coating a charged particle is attracted to the nearest ground object where there is an opposite image charge (Miller and Barringer 2002). The charged particle induces an image charge on the target surface and according to Coulomb's law, when the distance between the charged particle and the target surface is small, strong adhesion will occur (Halim and Barringer 2007). Electrostatic coating has a variety of applications including painting, photo copiers, and in the food industry. In the food industry electrostatic powder coating can improve uniformity in coating (Yousuf and Barringer submitted).

Electrostatic coating of calcium has been shown to improve firmness in tomatoes (Rao and Barringer 2006). Electrostatic coating produces higher transfer efficiency than nonelectrostatic coating (Miller and Barringer 2002; Sumawi and Barringer 2005; Halim 
and Barringer 2007). Dustiness decreases with electrostatic coating (Ricks and Barringer 2002). In small powders if resistivity is high, the adhesion is also significantly higher (Halim and Barringer 2007). A problem with electrostatic coating is back ionization in which excess charge buildup causes particles to repel off the surface (Cross 1981).

\subsubsection{Electrostatic Forces:}

Electrostatic coating can be applied using a variety of methods such as corona gun, and tribocharging. A corona gun creates an electric field using high voltage wires. When particles pass through the corona zone they acquire a charge and are attracted to the nearest grounded substrate (Biehl and Barringer 2004). Tribocharging guns charge particles by friction rather than by corona and are able to apply a higher net charge to the powder with fewer free ions (Cross 1981).

\subsubsection{Particle size and electrostatic coating}

The larger the charge a powder has the greater the attraction for the substrate. While large particles hold greater charge and total force, total force per unit mass and charge to mass ratio is higher for smaller particles. Higher charge particles repel further and have a more uniform deposition (Biehl and Barringer 2004). Particles repel due to repulsion of similar charged particles. Though smaller particles have less total surface area they have greater surface area contact so they can carry a higher charge to mass ratio than their larger counterparts during electrostatic application (Miller and Barringer 2002). Electrostatic adhesion is stronger for small sucrose particles less than $100 \mu \mathrm{m}$ (Halim and 
Barringer 2007). For sucrose particles ranging from 100 to $450 \mu \mathrm{m}$ in size adhesion was approximately $80 \%$ (Halim and Barringer 2007). For particles larger than $100 \mu \mathrm{m}$ adhesion does not change with size and there was no significant difference between electrostatic and nonelectrostatic adhesion (Halim and Barringer 2007). Mayr and Barringer (2006) found that adhesion of sucrose on graham crackers decreases from approximately $98 \%$ to $80 \%$ when particle size increases from 13 to $140 \mu \mathrm{m}$ for both corona and tribocharging. Transfer efficiency of sucrose particles increases with particle size leveling off near $80 \mu \mathrm{m}$ for both triboelectric and corona charging (Mayr and Barringer 2006). Flake 1a crystals had better coating efficiency than dendritic salts and cubic salts (Miller and Barringer 2002).

However because van der Waals forces per unit mass are stronger in smaller particles many studies have found no significant difference between electrostatic and nonelectrostatic coating of small powders (Mayr and Barringer 2006; Halim and Barringer 2007). Mayr and Barringer (2006) find that electrostatic transfer efficiency and adhesion of particles $13-80 \mu \mathrm{m}$ in size was higher than nonelectrostatic coating

\subsubsection{Resistivity and electrostatic coating}

Resistivity is how readily an object accepts charge. The higher the resistivity the more difficult it is to charge the object, but once the high resistivity object obtains charge it is less likely to lose the charge. Materials that carry charges high enough to allow electrostatic forces to contribute significantly to the total force of adhesion are generally 
polymers of poor conductivity or other extreme insulators (Bowling 1988). Intermediate resistivity powders $\left(10^{11}-10^{13} \Omega \mathrm{m}\right)$ had higher electrostatic adhesion then powders with resistivity less that $10^{10} \Omega \mathrm{m}$ (Halim and Barringer 2007). On an oily product such as potato chips or pork rinds electrostatic coating does not have a significant effect. Potato chips have high resistivity due to oil which minimizes charge leakage from ground to target resulting in weak coulomb forces (Halim and Barringer 2007).

\subsubsection{Positive vs. negative electrostatic coating}

There is theoretically no difference in charging powders using positive corona compared with negative corona. However, when positive polarity is used more of the energy is converted into an electric field than when negative polarity is used. Therefore it is believed with positive corona, since there is more charge available there will be a higher charge on the particles, and maybe greater transfer efficiency and adhesion for the same voltage setting. Powders such as protein with positive tribocharging values have greater transfer efficiency when coated with positive corona while powders coated with negative tribocharging values have higher transfer efficiency when coated with negative corona (Sumawi and Barringer 2005). Most salts have small tribocharging values and transfer efficiency for both positive and negative corona are equal (Sumawi and Barringer 2005). 


\subsection{Manufacturing potato chips}

\subsubsection{Potato properties}

Potatoes are grown primarily in the northwestern part of the United States and are stored for up to approximately 10 months for year round usage (Tsai and others 2001). Initially potatoes are tested for temperature, specific gravity, reducing sugars, size and defects. A critical test for the sugar sucrose is important for stored potatoes so that chips produced are not dark in color. Low specific gravity chips are rejected since they have high moisture content. Potatoes with high specific gravity have low moisture content which can lead to chips with more breakage. Hot potatoes tend to respire and turn mushy, and cold potatoes tend to have a reducing sugar problem. Very large or very small potatoes create problems during processing and also effect bulk density.

\subsubsection{Potato pre manufacturing and post manufacturing protection:}

Bacterial soft rot, caused by bacterium Erwin carotovora, is the most common potato disease that induces rapid and heavy spoilage loss (Tsai and others 2001). The use of acidified oxine has been shown to be effective in preventing potato spoilage without risks of chemical residual or change in skin color (Tsai and others 2001). Many applications have been tested to retard transport of gases for fruits and vegetables as well as for dried/immediate moisture foods. A stearic palmitic acid blend edible film can provide an improved water vapor barrier, and oxygen barrier increasing overall potato quality by 43 days at $50 \%$ RH (Park and others 1996). 


\subsubsection{Potato chip properties}

Potato chips are thin potato slices with moisture content of $0.02 \mathrm{~kg} / \mathrm{kg}$ or less (Pedreschi and Moyano 2005b). Very thin chips are more oily and susceptible to breakage, whereas very thick chips take longer to fry and have high final moisture content. Potato chips have oil content between 35-45\% wet basis (Pedreschi and Moyano 2005a). Potato chips also contain resistant starch. Resistant starch is the sum of starch and products of starch degradation not absorbed by the small intestine of healthy individuals. Resistant starch is very low in fresh fried chips but increases when thermal degradation of starch in the absence of water occurs such as when chips are freeze dried before frying (Goni and others 1997).

\subsubsection{Potato chip frying}

As potatoes fry, internal cells become dehydrated and evaporated water is partially replaced by frying oil (Moreira and others 1997). Frying is usually done at an oil temperature of $190^{\circ} \mathrm{C}$ for $4 \min$ (Berry 2003). Crust formation occurs after the potato tissue has been exposed to hot oil of 170 to $180^{\circ} \mathrm{C}$ (Pedreschi and others 2001). Higher frying temperatures accelerate crust formation, decreasing oil uptake (Pedreschi and others 2001). Higher frying temperature also means the oil has less density and is not easily absorbed (Berry 2003). Potato chips sliced between 1-2 mm thick are fried for 1.5 to $3 \mathrm{~min}$ at 170 to $190^{\circ} \mathrm{C}$ in a continuous fryer (Pedreschi and Moyano 2006).

\subsubsection{Reducing browning in potato products:}


Potatoes are high in the amino acid asparagine which is considered a crucial participant in the product of acrylamide by maillard reaction (Pedreschi and Kaack 2004). Blanching is a method to slow browning, reduce asparagine content and glucose, and gelatinize surface starch in thick potato slices (Pedreschi and Moyano 2006). Another method shown to reduce browning in french fries is addition of sodium acid pyrophosphate solution which reduces enzymatic browning (Bunger and others 2003). To reduce acrylamide formation $\mathrm{pH}$ can be lowered and blanching should be done prior to frying. However, reducing the $\mathrm{pH}$ and blanching are not practical solutions to perform in a commercial setting.

\subsubsection{Texture analysis of snack foods:}

Texture is a sensory perception that humans can describe and with various methods quantify (Pedreschi and Moyano 2005b). Scanning electron microscopy is a common method to examine swelling and crystal structure of starch granules. Bouchon and others (2003) used confocal laser scanning microscopy to see oil distribution with sample cross sections. Quantitative difference in stringiness or shortness of gels or pastes can be measured using the Instron device. The food to be tested is placed under tension of a roughened disc suspended from an Instron tension cell. By lowering the food at a controlled rate, the tension is recorded on a chart while the extension at which the resulting string of food ruptures is noted (Henry and Katz 1969). A puncture texture analyzer can determine the texture with the maximum force being the point at which the 
puncture force broke through the surface of the chip (Pedreschi and Moyano 2005ab). Measuring force at different temperatures characterize textural changes during frying.

\subsection{Oil:}

\subsubsection{Oil distribution}

Many factors influence oil uptake including frying temperature and duration, product shape, product composition, porosity, and pre frying treatments (Kawas and Moreira 2001). Oil is mostly absorbed during the cooling period after slices are removed from the fryer (Bouchon and others 2003). Also oil uptake is considered to be surface phenomena involving equilibrium between adhesion and drainage of oil (Bouchon and others 2003). A given surface can only hold a certain amount of oil. Adding additional oil beyond the maximum holding capacity will cause the oil to drain off the chip (Bouchon and others 2003).

\subsubsection{Time and temperature and surface oil content}

During frying $20 \%$ of the total oil is absorbed by chips. $36 \%$ of the total oil is on the surface and $64 \%$ of the total oil is absorbed during the cooling period (Moreira and others 1997). Increasing frying time will increase total oil penetration (Bouchon and others 2003). During cooling oil viscosity increases, and surface tension and interfacial tension between the air and oil increases allowing oil to enter inside the chip through the pores (Moreira and others 1997). Increasing porosity in restructured potato cylinders produces higher oil uptake (Pinthus and others 1995). 
Gould (1994) found adhesion increases by $13 \%$ if chips are coated at $149{ }^{\circ} \mathrm{C}$ compared with chips coated at $38^{\circ} \mathrm{C}$.

\subsubsection{Measuring total oil content}

A common method for total oil content measurement is using soxhlet extraction with petroleum ether (Bouchon and others 2003; Moreira and others 1997). Hexane may also be used as the solvent in the soxhlet extraction method as it is used in the extraction of oil from tortilla chips (Enggalhardjo and Narsimhan 2005). Total oil can also be measured by extraction with a mixture of chloroform, methanol and water (Pedreschi and Moyano 2005ab). Another method to measure total oil content is using the Carver press, but in order to insure accuracy this method requires comparison with a standard curve

\subsubsection{Measuring surface oil content}

Surface oil content can be measured by washing tortilla chips for 1-2 sec in petroleum ether (Moreira and others 1997). Nonencapsulated fat from a complex of whey protein concentrate and conjugated linoleic acid is determined by dispersing the product in hot $\left(60-80^{\circ} \mathrm{C}\right)$ petroleum ether for 10 min followed by decantation of the solvent and drying of the residue in an oven until a constant weight is achieved. Calculations are made to determine surface conjugated linoleic acid content (Jimenez and others 2004). Nonencapsulated oil from the surface of a powder containing acacia gum, maltodextrin glucidex and vegetable oil is determined by washing the surface of $20 \mathrm{~g}$ powder with 
petroleum ether followed by drying and gravimetrically determining the surface oil (Turchiuli and others 2005).

Complete surface oil content extraction from tortilla chips may also be done by placing chips in hexane for 20 min (Enggalhardjo and Narsimhan 2005). Surface oil was determined from spray dried powder complex containing cardamom oil and mesquite gum. The powder is placed in an extraction thimble and covered with glass wool, the powder is extracted with hexane for $4 \mathrm{hr}$, followed by drying in water bath and vacuum oven and determining the weight of the residue (Beristain and others 2001).

Soottitantawat and others (2005) describe that surface oil can be determined by washing $1 / 10$ gram of encapsulated D-limonene powder in $1 \mu \mathrm{l} / \mathrm{ml}$ cyclohexane, followed by mixing, filtration, and gas chromatography of the organic phase. Surface oil was extracted from a powdered complex of lemon oil and b-cyclodextrin by washing the powder with hexane for $10,20,30,45$, and 60 min followed by gas chromatography (Padukka and others 2000). More than $85 \%$ of surface oil is extracted within the first 10 min by washing in hexane (Padukka and others 2000).

The soxhlet method is also used to determine surface oil content using hexane as the solvent for 1,2 , and $3 \mathrm{hr}$ followed by placement of concentrated D-limonene powder and cyclohexane solution in a rotary evaporator and then nitrogen evaporation (Padukka and others 2000). The soxhlet method for extracting surface oil did not increase surface 
oil amount with time and removes encapsulated flavor components (Padukka and others 2000).

In order to extract surface oil from dried starch complex powders a mixture of hexane and 2-octanone in pentane is used (Finney and others 2002). The powder is placed in the solution and shook for $10 \mathrm{~min}$. The extract is filtered and evaporated under nitrogen. The amount of oil in the sample is determined by gas chromatography (Finney and others 2002). Surface lipids of milled head rice samples is obtained by extraction with $8 \mathrm{ml}$ isopropanol during vortexing, followed by determining free fatty acid content of extracts colorimetrically (Feliz and others 2005).

Surface oil is measured from sesame seeds using dried filter paper to absorb the oil during heating at $200{ }^{\circ} \mathrm{C}$ for $3 \mathrm{~min}$ followed by extracting the paper with diethyl ether (Takenaka and others 2006). Surface oil can be determined from chopped coconut pieces by measuring an increase in weight of blotting papers, used to blot the oil on the surface of the coconut samples for $12 \mathrm{hr}$ (Niamnuy and Devahastin 2005).

\subsubsection{Reducing oil absorption in potato chips:}

Higher oil temperature results in lower oil uptake in fried potato slices (Pedreschi and Moyano 2005a). Higher oil temperature causes rapid softening of tissues and not hardening of the crust (Pedreschi and Moyano 2005a). Lower moisture content also leads to less oil uptake (Pedreschi and Moyano 2005a). Decreasing flour particle size has also been shown to decrease oil absorption in fried snacks (Singh and Seetha 1993). In 
laboratory scale experiments in order to reduce oil content potato chips are blotted using paper and blanching is done prior to frying. Blanching causes gelatinization of the surface starch reducing oil uptake (Califano and Calvelo 1987). In a commercial setting air knives spin at high velocities to blow off excess oil. Air knives can reduce fat content of chips from $35 \%$ to $20 \%$ or lower (Berry 2003).

\subsubsection{Reducing oil absorption in french fries:}

To reduce oil absorption in thick potato slices such as french fries methods such as vacuum frying, $\mathrm{NaCl}$ soaking, pre-drying, adding fructose and blanching can be utilized (Pedreschi and Moyano 2005a). These methods would not work on a large quantity of products. Blanching in calcium and magnesium salt solution results in binding of pectin substances on the surface of french fries which can save the structure of potato cells throughout the frying process (Czopek 2003). Soaking potato strips in 3\% w/w NaCl concentration and 50 min soaking time reduces oil uptake and increases hardness and sensory texture quality of french fries without modifying color, moisture content and sensory acceptability (Bunger and others 2003).

\subsubsection{Reducing oil absorption with batters}

Coatings are also a good way to prevent oil migration. Batters are liquid dough basically consisting of flour and water, into which a product is dipped before it is fried. Balls of frozen fried potatoes coated with pectin formulation show no oil migration after four months compared to control samples which have no coating applied (Brake and 
Fennema 1993). However, a thick not very viscous batter is capable of releasing a large quantity of water which produces a porous coating that absorbs a lot of oil (Fizman and Salvador 2003).

\subsubsection{Oil composition}

Using different oil types to fry chips can affect the amount of seasoning that will adhere to the chips. Enggalhardjo and Narsimhan (2005) found that adhesion force required to remove seasoning from tortilla chips sprayed with olive oil is higher than chips sprayed with the same amount of soybean oil. This increase in adhesion force is explained by a difference in viscosity, in which olive oil being more viscous required higher adhesion force than soybean oil. Though olive oil requires a higher adhesive force to remove the seasoning, the amount of seasoning lost from both chips sprayed with olive oil and chips sprayed with soybean oil is the same (Enggalhardjo and Narsimhan 2005).

\subsubsection{Oil stability:}

The quality of oil used for frying affects the potato chips taste and storage stability. Oxidative stability is examined by many parameters such as peroxide value, acid value, kreis test, p-anisidine value, TBA test, and sensory evaluation (Jonnalagada and others 2001). Using high oleic soybean oil has shown to give good frying stability and good oxidative stability (Warner and Gupta 2005). Freeze drying chips have high final oil content because there is no starch gelatinization leaving the structure with open

small pores. Peroxide values of chips fried in partially hydrogenated canola oil were as 
stable as those fried in cottonseed oil indicating that partially hydrogenated canola oil can also be used to fry and store chips (Melton and others 1993). 


\section{CHAPTER 3}

\section{MATERIALS AND METHODS}

\subsection{Preparation steps}

\subsubsection{Potato chips preparation}

White potatoes (Kroger, Cincinnati, $\mathrm{OH}$ ) were sliced 1-2 mm thick using a meat slicer (Model MS 1043-W Rival, Kansas City, MO) and cut into a final square shape of $2.54 \times 2.54 \mathrm{~cm}$ using a aluminum square mold. Eight potato chips placed in a basket were fried in $750 \mathrm{ml}$ to $1000 \mathrm{ml}$ soybean oil for $4 \mathrm{~min}$ at $190^{\circ} \mathrm{C}$ in a batch fryer (Model CF151, Rival, Milford, MA). To produce low surface oil content chips, individual potato chips immediately after frying were patted on both sides with a paper towel. To produce no surface oil content chips, fried chips were immediately placed in $250 \mathrm{ml}$ hexane for 20 min. High and low surface oil content chips were coated with $259 \mu \mathrm{m}$ flake salt after frying in five different oils; soybean (Kroger, Cincinnati OH ), corn (Kroger, Cincinnati, $\mathrm{OH}$ ), olive (Bertolli, Italy), peanut (Lou Ana, Opelousas, LA) and coconut (Lou Ana, Opelousas, LA). Chips of all surface oil contents were coated with $259 \mu \mathrm{m}$ flake salt at delayed time intervals of 1 day and 1 month. To determine the effect of temperature, fried chips with high, low and no surface oil content were heated at 50 and $70{ }^{\circ} \mathrm{C}$ using a dry oven for a total of $6 \mathrm{~min}$. Chips were also heated for a total of $6 \mathrm{~min}$ at 93, 149, and 204 
${ }^{\circ} \mathrm{C}$ using a conventional oven. During the heating process, chips were removed after 4 min, weighed and replaced in the oven for an additional 2 min. Immediately after heating, chips were coated with $259 \mu \mathrm{m}$ flake salt. One set of chips from each of the surface oil content levels were maintained at room temperature, $22^{\circ} \mathrm{C}$.

Eight chips from each surface oil content level were coated manually using salt shakers. Amount of salt added varied between 3-15\% depending upon size and shape of salt. $\mathrm{NaCl}$ crystals of five different particle sizes: $24.7 \mu \mathrm{m}$ (Extra fine flour salt, Morton Salt, Chicago, IL), $123 \mu \mathrm{m}$ (Fine Flour Prepared Premier, Cargill, Minneapolis, MN), 259 $\mu \mathrm{m}$ (Alberger Fine Flake, Cargill, Minneapolis, MN), $291 \mu \mathrm{m}$ (Alberger Flake, Cargill, Minneapolis, MN), $388 \mu \mathrm{m}$ (Alberger Coarse Flake, Cargill, Minneapolis, MN) were coated onto the chips. $\mathrm{NaCl}$ crystals of three different particle shapes: cubic (TFC 999, Purex Fine Prepared, Morton Salt, Chicago, IL), dendritic (ES and SF Dendritic, Morton Salt, Chicago, IL), flake lab (Alberger fine and Coarse flake, Cargill, Minneapolis, MN) and flake 2 (Top Fine Flake, Morton Salt, Chicago, $I L$ ) were coated onto the chips.

\subsubsection{Electrostatic coating}

Chips of all surface oil content levels were coated with five different salt sizes using an electrostatic powder applicator (Figure 3.1) (Terronics Development Corporation, Elwood, IN). Chips were placed on an aluminum foil conveyor belt moving at $2.88 \mathrm{~cm} / \mathrm{s}$. Salt was delivered at a flow rate of $0.72 \mathrm{~g} / \mathrm{s}$. Due to the large size of the 388 $\mu \mathrm{m}$ flake salt the flow rate was adjusted to $0.51 \mathrm{~g} / \mathrm{s}$. The salt was negatively charged 
electrostatically as it passed through the corona zone created by two high voltage wires charged at $-25 \mathrm{kV}$. The airflow for the machine was set at $25 \mathrm{psi}$ for direct left, $25 \mathrm{psi}$ for direct right, and 15 psi for back inject. Compressed air was supplied from an air compressor (Model 5F237G, 3 gallon tank, Dayton Electric Co, Niles, IL). An air dryer (Model IDFE-10-S, SMC Corporation, Tokyo, Japan) was used to supply dry air to prevent the salt from absorbing moisture.

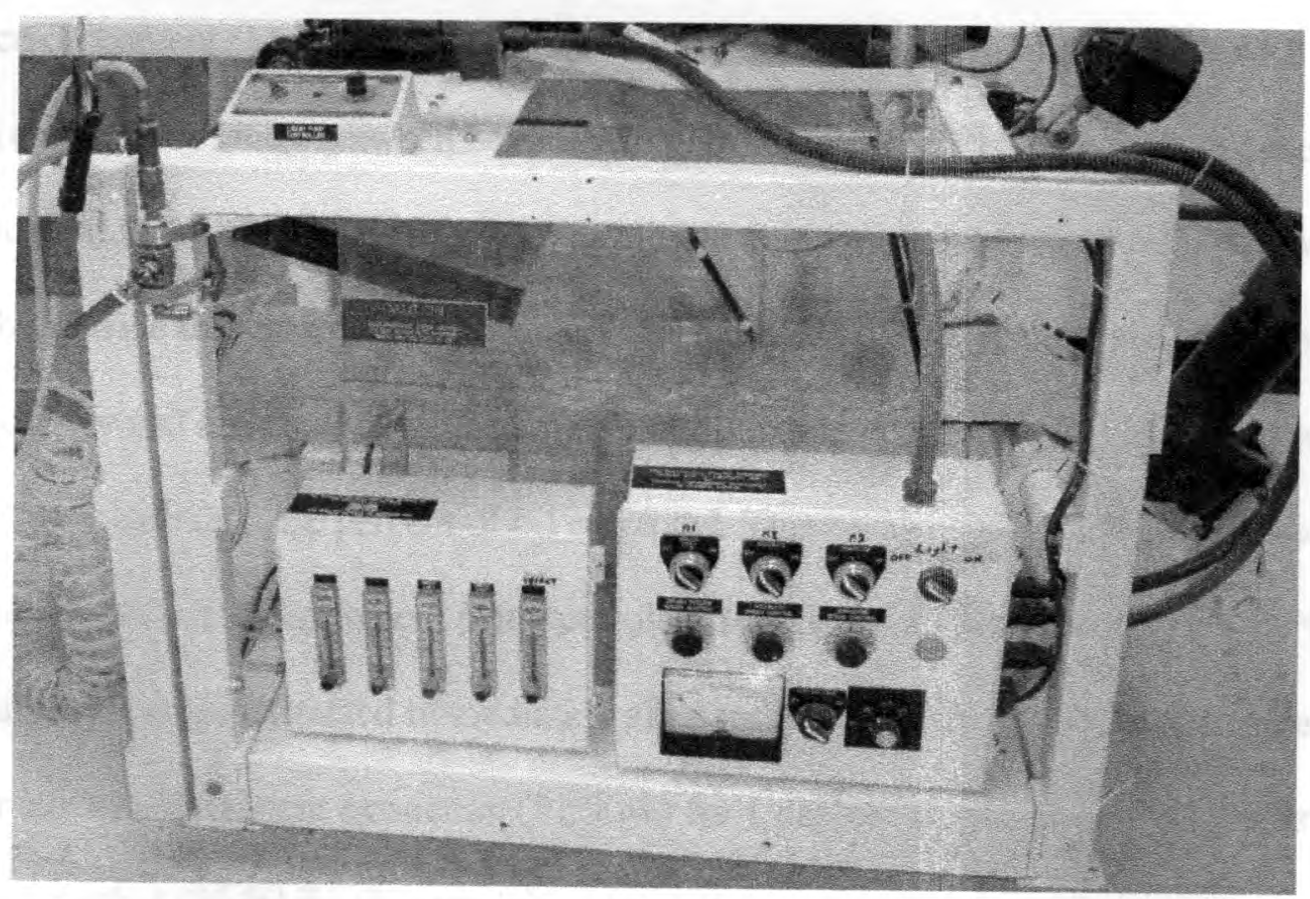

Figure 3.1: Electrostatic coating system 


\subsection{Analytical methods}

\subsubsection{Surface oil content (SOC)}

Surface oil content was measured by dipping each of the eight chips individually in a beaker of hexane for 1-2 sec. The difference in the weight of the empty beaker and after the hexane evaporated determined the surface oil content which is reported in $\mathrm{mg} / \mathrm{cm}^{2}$ (Table 3.1). Many studies have used petroleum ether as the solvent for measuring surface oil content (Moreira and others 1997). Using square aluminum chips 2.54 x 2.54 $\mathrm{cm}$, a comparison study between hexane and petroleum ether was done to determine the best solvent for extracting surface oil. Aluminum chips were used to ensure no oil was absorbed inside the substrate. Soybean oil was sprayed across the chips and extracted immediately and after one day. The amount of oil extracted was divided by the amount of oil added to calculate the percent of oil extracted. There was no significant difference in surface oil content measurement using petroleum ether $(83.85 \%)$ or hexane $(81.01 \%)$ for aluminum chips extracted immediately after spraying. However, hexane produced higher surface oil content extraction (81.90\%) for 1 day old aluminum chips compared to petroleum ether (56.90\%) (Figure 3.2). After 1 day, petroleum ether extracted less surface oil so there must have been polymerization which decreases the amount of oil extractable. For potato chips no difference in surface oil content was measured using either hexane or petroleum ether (Figure 3.3). Based on the results found with the aluminum chips, hexane was considered the better solvent, and used for measuring 
surface oil content. Hexane is a more nonpolar solvent than petroleum ether. The more nonpolar the solvent, the better it should be at dissolving nonpolar compounds such as oils.

\begin{tabular}{|c|c|c|}
\hline Surface Oil Content & $\mathrm{mg} / \mathrm{cm}^{2}$ & $\begin{array}{c}\text { Standard } \\
\text { deviation }\end{array}$ \\
\hline High & 15.50 & 2.61 \\
\hline Low & 1.59 & 0.44 \\
\hline No & 0.00 & 0.00 \\
\hline
\end{tabular}

Table 3.1 Amount of surface oil content (SOC) in high, low and no level chips

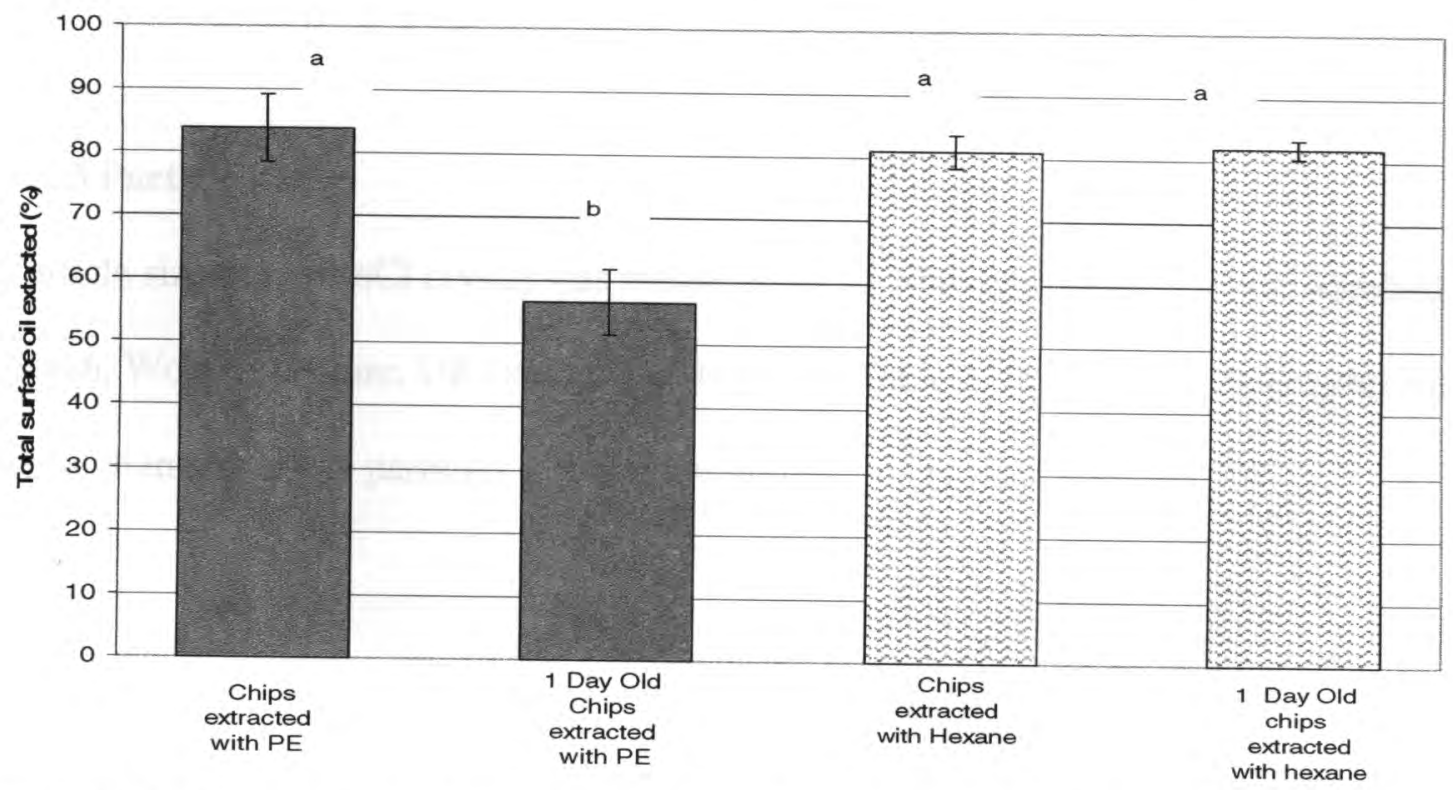

Figure 3.2: Comparison of percent of surface oil extracted using hexane and petroleum ether $(\mathrm{PE})$ on aluminum chips sprayed with soybean oil. Letters indicate significant difference between samples. 


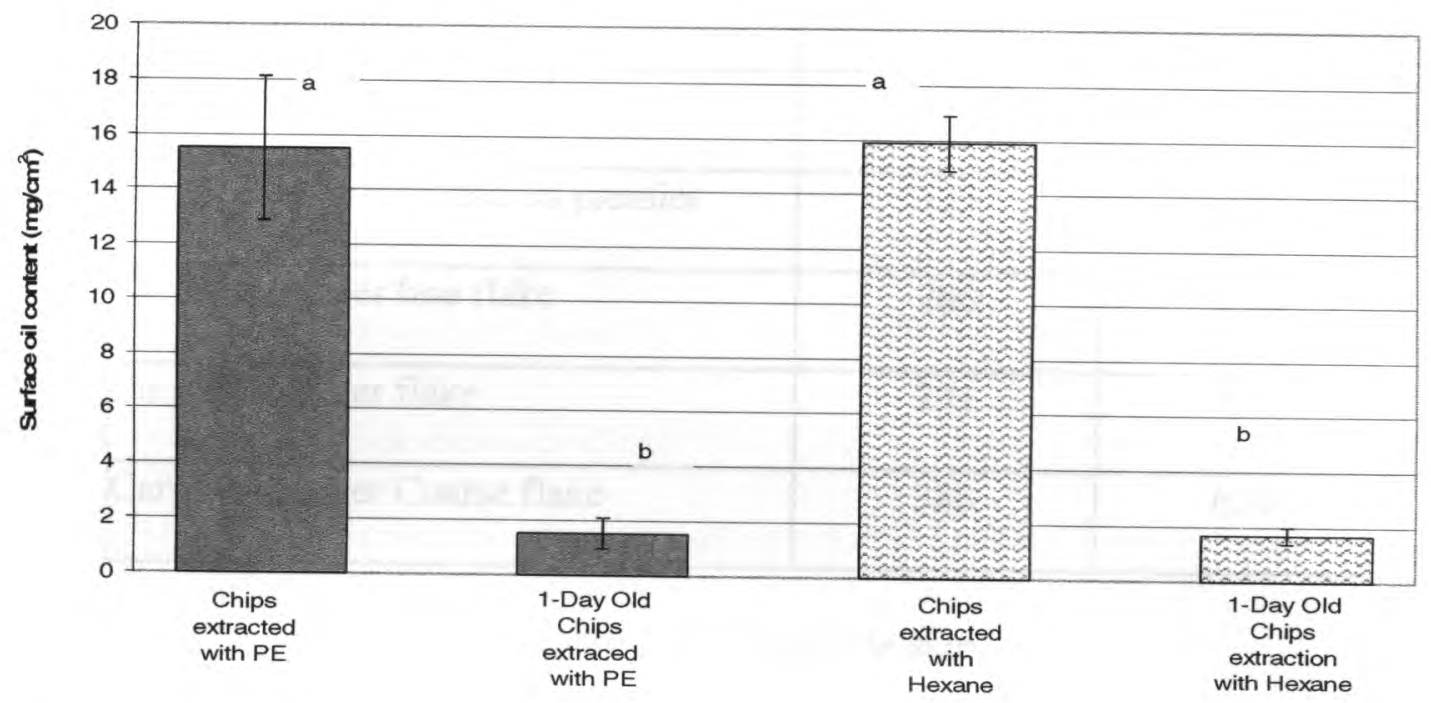

Figure 3.3: Comparison of percent of surface oil extracted using hexane and petroleum ether (PE) on potato chips sprayed with soybean oil. Letters indicate significant difference between samples.

\subsubsection{Particle size}

Particle size of the $\mathrm{NaCl}$ crystal was measured using Malvern Mastersizer (X standard bench, Worchestershire, UK) parameter [D (4,3)] (Table 3.2). This parameter gives the mean diameter of the particles in a given volume. 


\begin{tabular}{|l|c|c|}
\hline \multicolumn{1}{|c|}{ Commercial Name } & Size $(\mu \mathbf{m})$ & $\begin{array}{c}\text { Standard } \\
\text { deviation }\end{array}$ \\
\hline Morton extra fine flour salt & 24.8 & 1.66 \\
\hline Cargill Fine flour prepared premier & 123 & 2.83 \\
\hline Cargill Alberger fine flake & 260 & 1.84 \\
\hline Cargill Alberger flake & 291 & 5.75 \\
\hline Cargill Alberger Coarse flake & 388 & 6.88 \\
\hline
\end{tabular}

Table 3.2 Salt particle size

\subsubsection{Total Oil content calculation}

Assuming total oil does not change with temperature the amount of surface oil that should be on the potato chip surface at $100^{\circ} \mathrm{C}$ can be calculated according to the following equation:

Surface oil $(g)=S O C_{22}+\left(\left(V_{c 100}-V_{c 22}\right) D_{100}\right)$

Where $\mathrm{SOC}_{22}=$ measured surface oil content at $22{ }^{\circ} \mathrm{C}(\mathrm{g})$

$V_{c 100}=$ Volume of oil inside chip at $100^{\circ} \mathrm{C}(\mathrm{ml})$ calculated by determining the amount of oil inside chip $(g)$ which is equal to the total oil measured by 20 min extraction minus the amount of surface oil divided by density of oil at $100^{\circ} \mathrm{C}(0.87 \mathrm{~g} / \mathrm{ml})$

$V_{c 22}=$ Volume of oil inside chip at $22^{\circ} \mathrm{C}(\mathrm{ml})$ calculated by determining the amount of oil inside chip $(g)$ which is equal to the total oil measured by 20 min extraction minus the amount of surface oil divided by density of oil at $22^{\circ} \mathrm{C}(0.91 \mathrm{~g} / \mathrm{ml})$.

$D_{100}=$ density of oil at $100^{\circ} \mathrm{C}(0.87 \mathrm{~g} / \mathrm{ml})$ 


\subsubsection{Monolayer calculation}

It is important to determine how much salt is in a monolayer as adding more then a monolayer of salt will show lower adhesion (Cross 1975). The amount of salt in a monolayer was calculated according to the following equation:

Mass of salt $(g)=\left(D V_{s}\right)$

Where $D=$ density of salt is $2.2 \mathrm{~g} / \mathrm{cm}^{3}$

$V_{s}=$ volume of a salt crystal $=(\text { diameter of crystal })^{3} x[$ number of salt crystals (area of square potato chip / area of salt crystal)]

\begin{tabular}{|c|c|c|c|}
\hline $\begin{array}{c}\text { Salt size } \\
(\mu \mathrm{m})\end{array}$ & $\begin{array}{c}\text { Monolayer value } \\
(\mathrm{g})\end{array}$ & $\begin{array}{c}\text { Average amount of salt } \\
\text { added }(\mathrm{g})\end{array}$ & $\begin{array}{c}\text { Standard } \\
\text { deviation } \\
\text { (amount of salt) }\end{array}$ \\
\hline 24.7 & 0.03 & 0.16 & 0.06 \\
\hline 123 & 0.17 & 0.27 & 0.06 \\
\hline 260 & 0.37 & 0.27 & 0.13 \\
\hline 291 & 0.41 & 0.18 & 0.05 \\
\hline 388 & 0.55 & 0.23 & 0.05 \\
\hline
\end{tabular}

Table 3.3 Monolayer values 


\subsubsection{Vibration method for adhesion measurement}

A magnetic feeder (Homer City, PA) was closed off on the end using a piece of foam (Figure 3.4). The feeder tube was further divided into eight slots using foam dividers. The chips were placed coated side facing up inside the feeder. The feeder was set at a setting of 8 on a scale of 1-16 and allowed to vibrate for $15 \mathrm{~s}$. The chips were weighed before addition of salt, after addition of salt, and after vibrating chips to remove salt.

The equation used to measure adhesion is as follows:

Adhesion $(\%)=\frac{\text { Wt after shaking salt }- \text { Wt before coating }}{\text { Wt after coating }- \text { Wt before coating }} \times 100$

Note: All weights recorded in gram
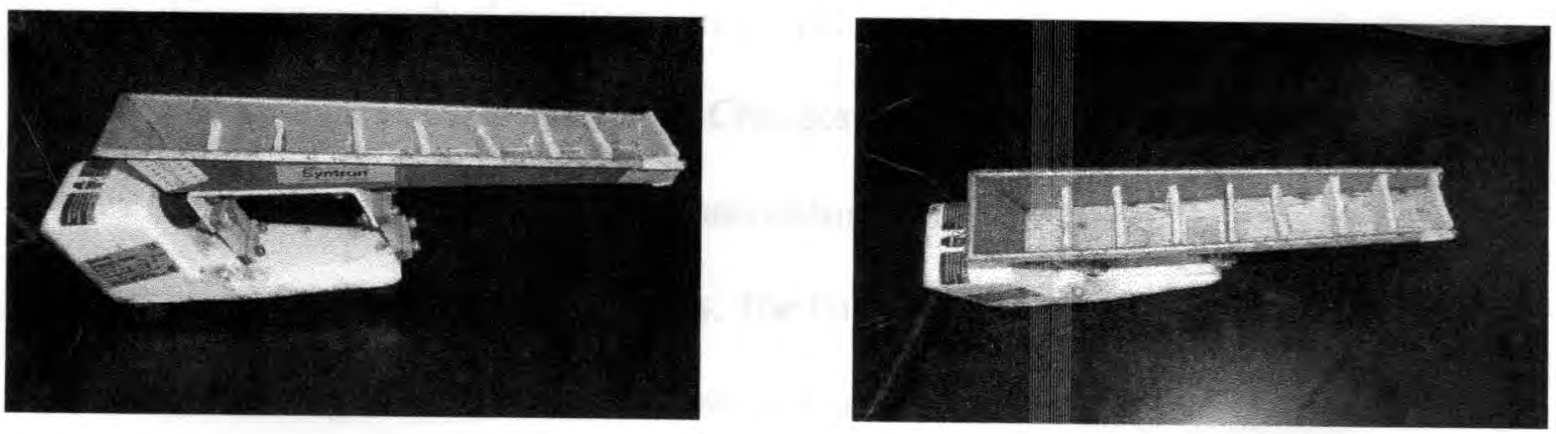

Figure 3.4: Adhesion measurement using a feeder

\subsubsection{Statistical Analysis}

Statistical analysis was done using Microsoft Excel. T-test with equal variances and ANOVA One/Two Factor tests with post hoc analysis using LSD were also done. P value $<\alpha=.05$ was used to indicate significantly different results. 


\section{CHAPTER 4}

\section{RESULTS AND DISCUSSION}

This study examined three major components and their attributes as they affected adhesion of salt onto potato chips. The first component examined was oil and factors that can change surface oil content such as physically reducing the oil by patting and extraction, time between frying and coating, temperature, and the use of different oils. The low surface oil chips which were patted to reduce surface oil content are most similar to commercial chips which have surface oil content reduced by air knives. Changes in oil amount affect the strength of capillary forces. The second component examined was salt and physical attributes of size and shape. Changes in salt size affect the strength of van der Waal forces and electrostatic forces, and changes in shape affect mechanical interlocking and number of contact points. The third component examined was the use of electrostatic coating with different salt sizes and surface oil contents. Electrostatic coating improves adhesion due to electrostatic image forces (Bowling 1988).

\subsection{Oil}

\subsubsection{Time between frying and coating}

For chips with high surface oil content $\left(15.50 \mathrm{mg} / \mathrm{cm}^{2}\right)$ increasing time between frying and coating by 1 day and 1 month did not change adhesion values (Figure 4.1). 
This was expected as the chips are very oily. Oily chips have strong capillary forces which dominate over van der Waals and electrostatic forces (Bowling 1988). During cooling, oil is absorbed inside the microstructure pores of the chips, however on high surface oil content chips there is apparently still enough surface oil remaining after 1 day and 1 month for strong capillary action to cause the high adhesion. Capillary forces increase adhesion by establishment of liquid and solid bridges (Enggalhardjo and Narsimhan 2005). Popcorn with high amounts of surface oil had higher transfer efficiency as oil holds the seasoning (Miller and Barringer 2002). For chips with low surface oil content $\left(1.59 \mathrm{mg} / \mathrm{cm}^{2}\right)$ there was a significant decrease in adhesion for 1 day old and 1 month old samples (Figure 4.1). This decrease in adhesion is due to a decrease in surface oil content and weak capillary forces. The decrease in surface oil content occurs because surface oil is absorbed into the crust microstructure of the product. For chips with no surface oil content $\left(0.00 \mathrm{mg} / \mathrm{cm}^{2}\right)$ there was no difference in adhesion between fresh, 1 day old, and 1 month old samples (Figure 4.1). This was expected because there was no difference in surface oil content. For chips with no surface oil content van der Waals forces are responsible for the adhesion observed. One of the primary forces for a dry uncharged particle on a dry uncharged substrate are van der Waals forces (Berard and others.2002). 


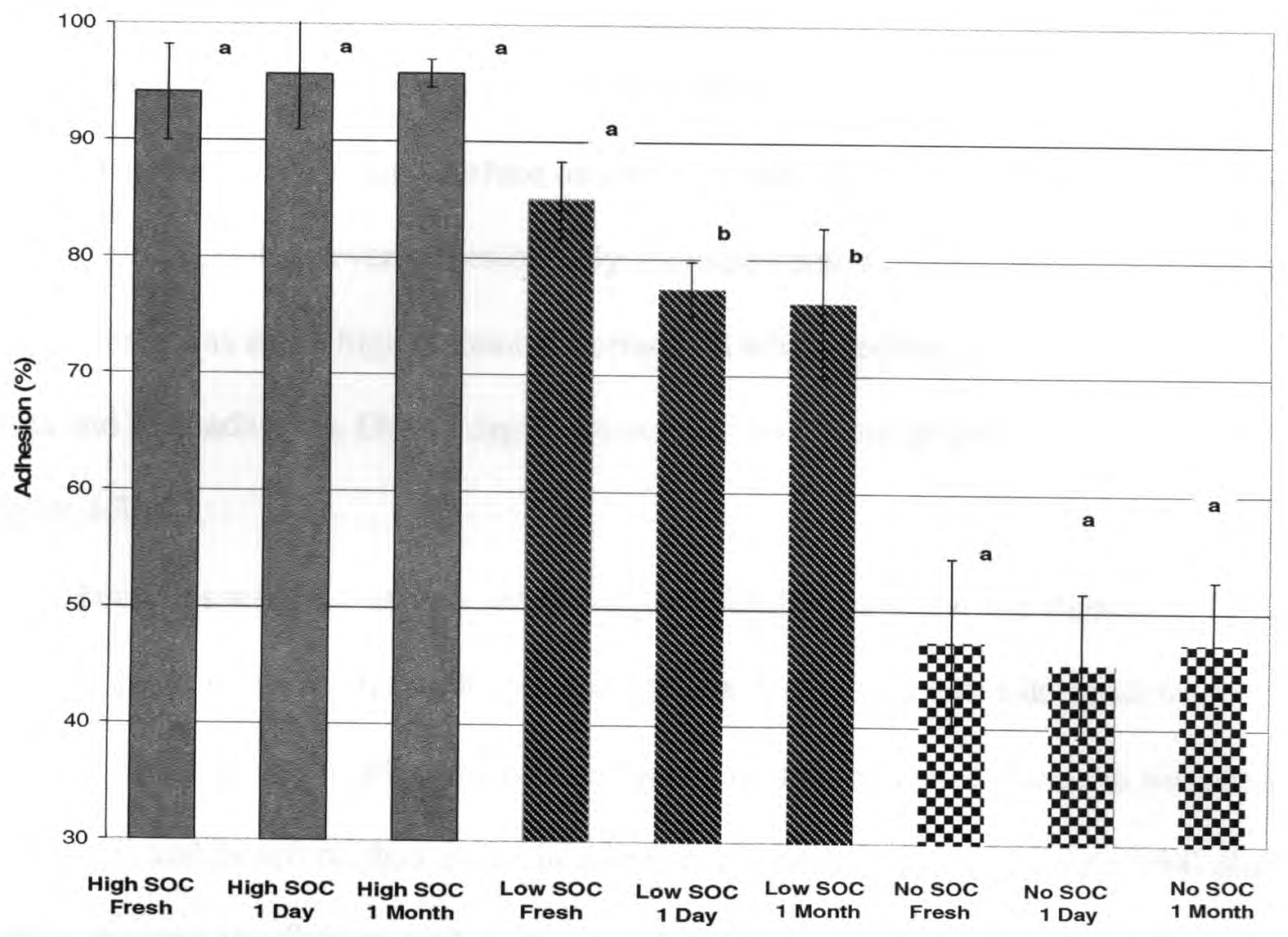

Figure 4.1: Effect of delaying coating on adhesion. Letters indicate significant difference between samples of the same surface oil content (SOC)

\subsubsection{Chip temperature effect on adhesion}

Immediately after removing potato chips from the fryer, surface oil is rapidly absorbed inside the chips (Bouchon and others 2003) making it difficult to measure adhesion during cooling. In order to simulate temperature changes that occur during cooling, potato chip samples were reheated to different temperatures. For high surface oil chips there was no change in adhesion from $204{ }^{\circ} \mathrm{C}$ to $70^{\circ} \mathrm{C}$ (Figure 4.2). Chips with high 
surface oil content had slightly lower adhesion with decreasing temperature from $70^{\circ} \mathrm{C}$ to $22{ }^{\circ} \mathrm{C}$. Decreasing chip temperature reduces oil on the surface, thus decreasing adhesion. The surface oil content of high surface oil chips decreased roughly linearly from $95^{\circ} \mathrm{C}$ to $22^{\circ} \mathrm{C}$ (Figure 4.3). However, adhesion only decreased below $70{ }^{\circ} \mathrm{C}$ (Figure 4.2). This is because there was still a high amount of surface oil which resulted in strong capillary forces and high adhesion. Over $3 \mathrm{mg} / \mathrm{cm}^{2}$ there was no further increase in adhesion (Figure 4.3).

For chips with low and no surface oil content chip adhesion was highest at $70^{\circ} \mathrm{C}$ (Figure 4.2). At temperatures both above and below $70^{\circ} \mathrm{C}$ there was a decrease in adhesion. The decrease in adhesion can be directly correlated with decrease in surface oil (Figure 4.3) and therefore changes in the strength of capillary forces. Gould (1994) also found a decrease in adhesion with decreasing temperature, comparing chips at $149^{\circ} \mathrm{C}$ and $38^{\circ} \mathrm{C}$. The decrease in surface oil content is significant for chips with high and no surface oil content. However, for low surface oil content chips the reduction in surface oil content did not provide significantly different values and this could be due to a difference in patting methods when reducing surface oil content.

As temperature decreases, oil density increases (Noureddini and others 1992). As density increases internal oil takes less volume and surface oil goes into the center of the chip. Oil expansion accounts for roughly half of the surface oil changes. This was calculated using the density of soybean oil at different temperatures (Noureddini and 
others 1992) and comparing the amount of oil that should be on the surface, assuming the total oil does not change with temperature, with the amount of surface oil experimentally measured. Chips with small pores have higher oil in the core and less oil on the surface (Kawas and Moreira 2001). At temperatures higher than $90^{\circ} \mathrm{C}$, surface oil decreased possibly due to oil oxidizing and chemically reacting with proteins inside the potatoes and polymerization. Increasing temperature accelerates the rate of oil oxidation (Dunford 2003). Heat could be causing physical damage to the pores not allowing all the oil to be released to the surface. At temperatures around $149^{\circ} \mathrm{C}$ and $204^{\circ} \mathrm{C}$ chips appeared dark brown indicating a chemical reaction had occurred and physical damage.

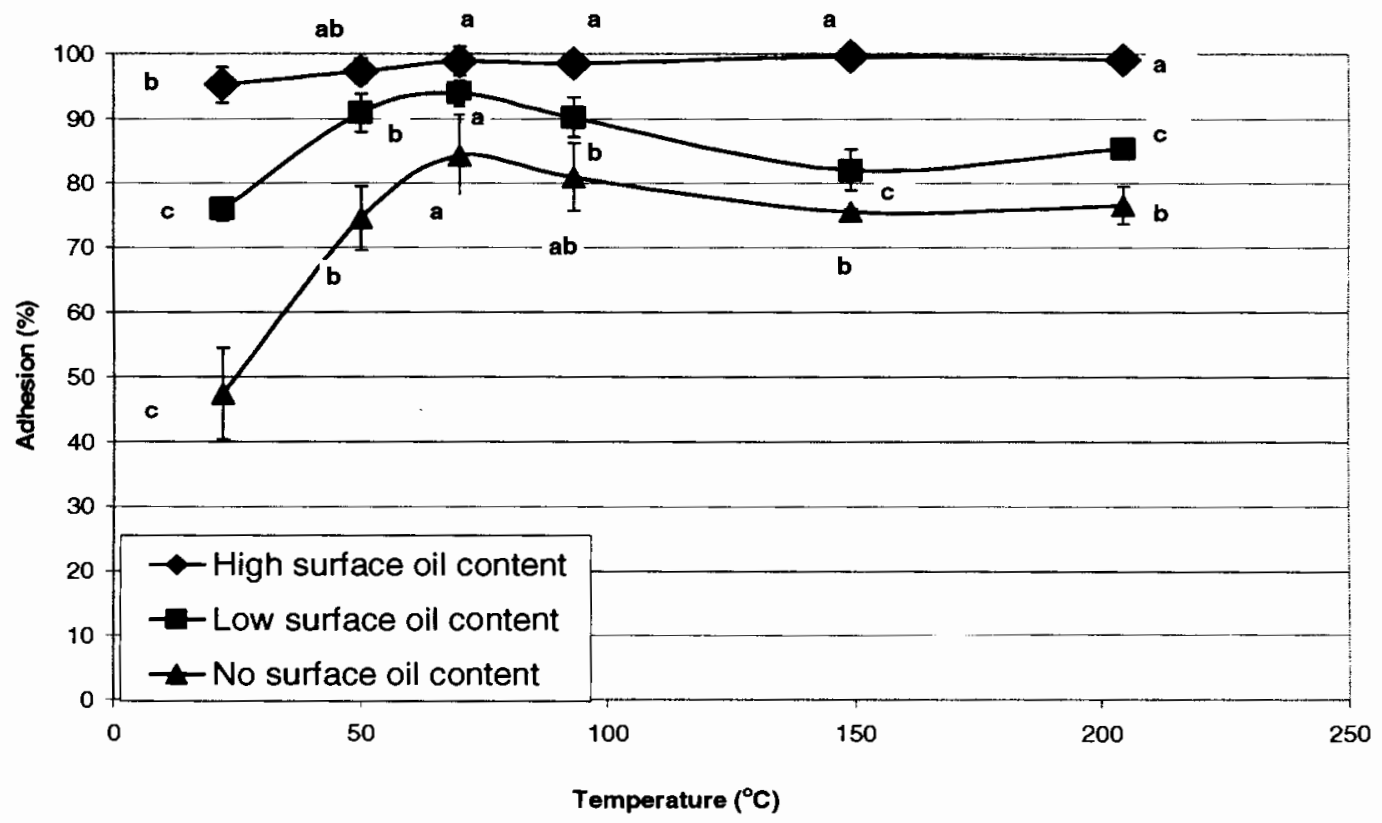

Figure 4.2: Effect of temperature on adhesion. Letters indicate significant difference between samples of the same surface oil content. 


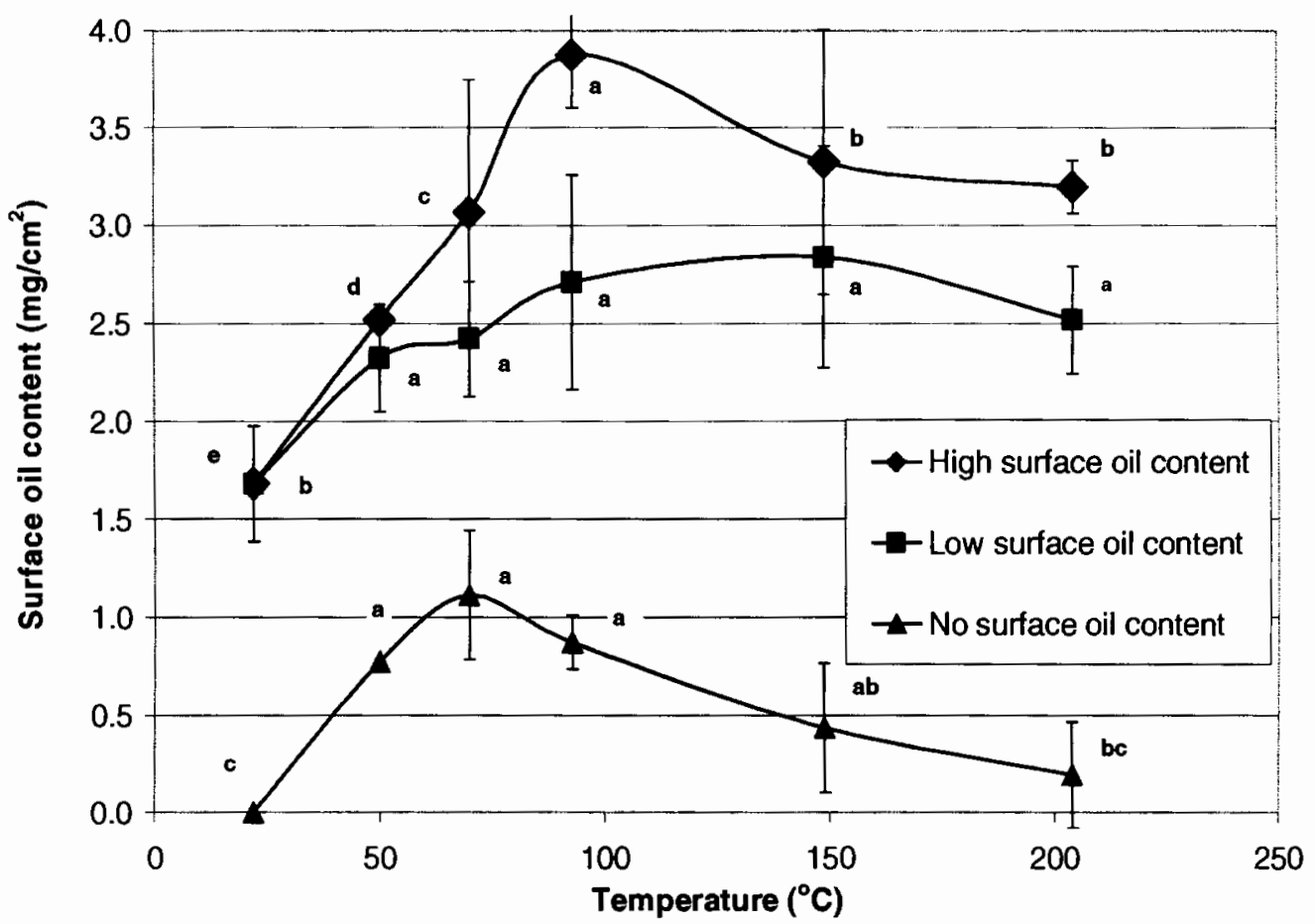

Figure 4.3: Relationship between chip temperature and surface oil content. Letters indicate significant difference between samples of the same surface oil content

\subsubsection{Oil composition effect on adhesion}

Monosaturated olive, peanut, and soybean oils were compared with polyunsaturated corn oil and saturated coconut oil. Changing oil composition produced no difference in adhesion for either high or low surface oil content chips (Figure 4.4). In this study no significant differences in adhesion between different oils could be due to similar viscosities of the oil as coating was applied to hot chips. Adhesion does not significantly differ when tortilla chips are sprayed with olive oil compared to soybean oil (Enggalhardjo and Narsimhan 2005). Though oil viscosities for soybean and olive oil are 
different and the calculated adhesion force is different the amount of seasoning adhering to the tortilla chips is not significantly different (Enggalhardjo and Narsimhan 2005).

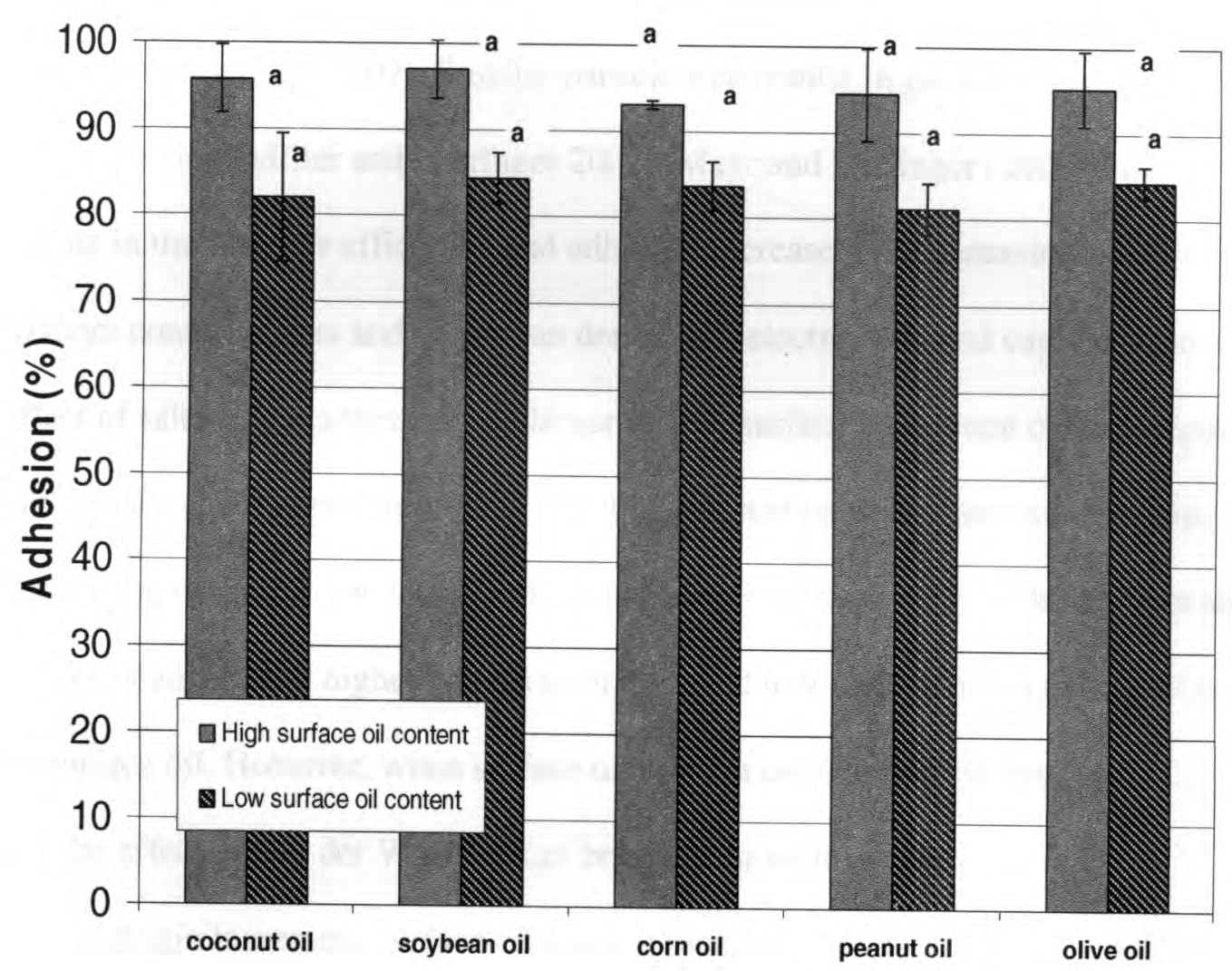

Figure 4.4: Effect of different frying oils on adhesion. Letters indicate significant difference between samples of the same surface oil content

\subsection{Salt}

\subsubsection{Salt size effect on adhesion}

Adhesion of salt to the potato chip surface significantly decreased with increasing salt size for all surface oil content chips (Figure 4.5). Adhesion of small salts is primarily 
due to van der Waals forces (Bowling 1988). Large particles have more particle contact area than smaller particles, however van der Waals force per mass decrease (Halim and Barringer 2007). Smaller particles have better adhesion than larger particles (Niman 2000; Halim and Barringer 2007). Smaller particle size results in greater transfer efficiency during coating (Miller and Barringer 2002). Mayr and Barringer (2006) find opposite results in that transfer efficiency and adhesion increase with increasing particle size due to more contact points and larger van der Waals, electrostatic and capillary forces. The effect of salt size on adhesion was larger on low surface oil content chips compared to high surface oil content chips. The effect of salt size on no surface content chips was even greater than for low surface oil chips. Larger size salt such as the $291 \mu \mathrm{m}$ and 388 $\mu \mathrm{m}$ had significantly higher adhesion on high and low surface oil chips than chips with no surface oil. However, when surface oil content decreases capillary forces decrease, and the effect of van der Waals forces becomes more important.

Again increasing surface oil content increased adhesion. At high and low surface oil content adhesion was not different for small sizes $(24.8 \mu \mathrm{m}$ to $260 \mu \mathrm{m})$. However at low surface oil content, salts sizes larger than $260 \mu \mathrm{m}$ showed a decrease in adhesion. Lower surface oil content decreases adhesion due to weak capillary forces and with increasing particle size van der Waal forces decrease. 


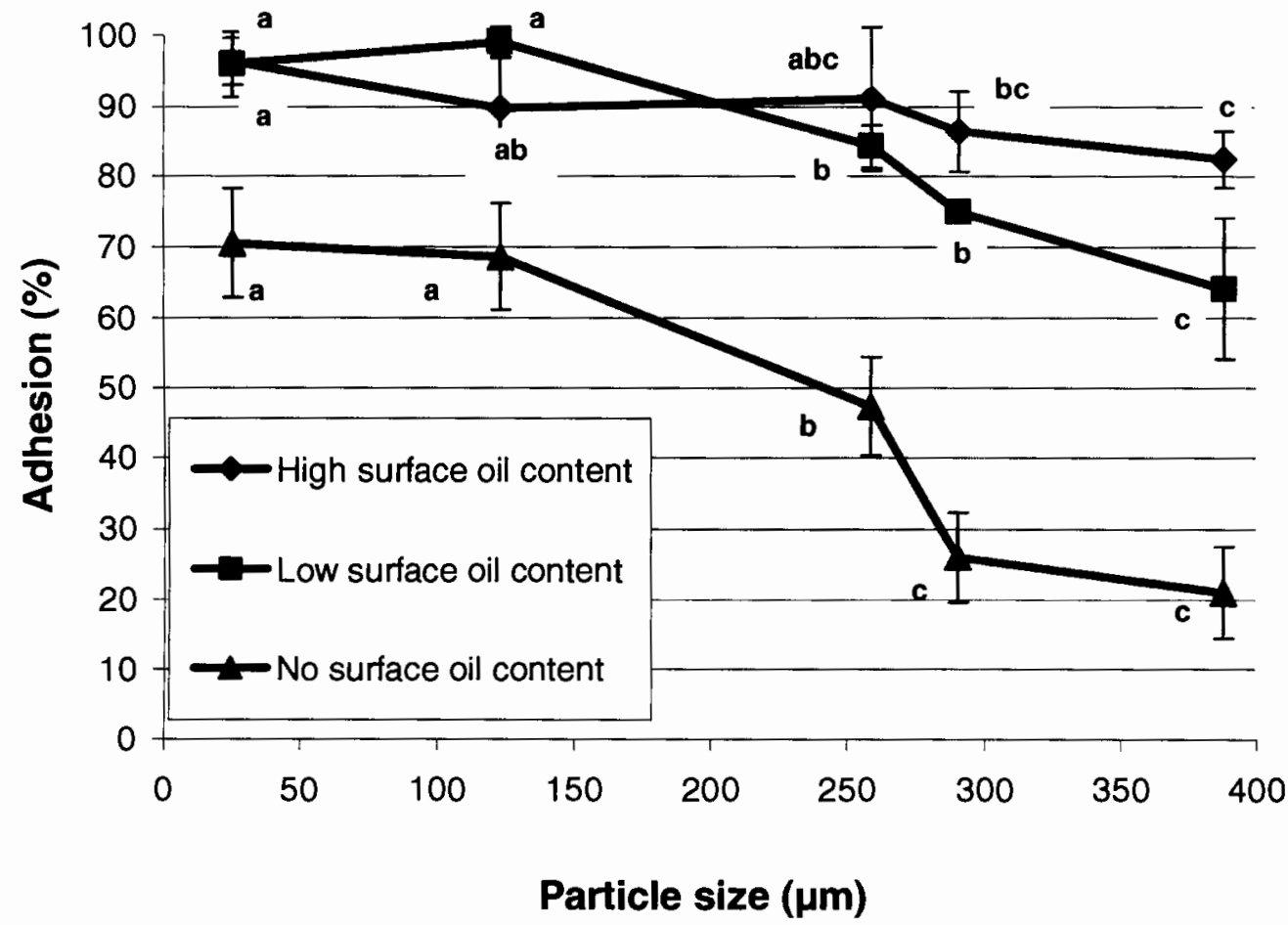

Figure 4.5: Effect of salt size on adhesion. Letters indicate significant difference between samples of the same surface oil content

\subsubsection{Salt shape effect on adhesion}

For chips with high surface oil content and coating small size crystals, crystal shape had no effect on adhesion because of strong capillary forces (Figure 4.6). However for large size salts adhering to high surface oil content chips, cubic shaped crystals gave better adherence then flake shape crystals. For chips with low surface oil content, and small size crystals, cubic and flake 1a crystals gave the same adhesion followed by 
dendritic crystals (Figure 4.6). For large size salts adhering to low surface oil content chips, cubic crystals gave higher adhesion than flake $1 \mathrm{~b}$ and flake 2 crystals, which had the same adhesion. For chips with no surface oil content and small size, flake la crystals had same adhesion as both cubic and dendritic crystals which are different from each other. For large size salts adhering to no surface oil content chips, cubic and flake 2 crystals gave the same adhesion which was higher adhesion than flake $1 \mathrm{~b}$ crystals. Dendritic crystals are porous, star shaped modified cubes with high specific surface area and should give adhesion similar to flake salts (Morton 1997). Dendritic crystals are modified to be porous by addition of yellow prussiate of soda (sodium ferrocyanide) during the vacuum crystallization of brine (Strietelmeier 1988). The more porous the particle is the more mechanical interlocking will occur (Michalski and others 1997). Niman (2000) found dendritic salts have adhesion values similar to flake $1 \mathrm{ab}$ and flake 2 salts. Flake $1 \mathrm{a}$ and $1 \mathrm{~b}$ crystals are irregular with stair step sides which make them appear like a quadrilateral pyramid (Kuntz 1994). Flake 2 crystals are flat, smooth surfaced, rectangular aggregates (Morton 2004) and were expected to have lower adhesion than Flake 1a and $1 \mathrm{~b}$ crystal which have more mechanical interlocking due to their rough surface. Smooth particles have less mechanical interlocking and lower surface area for bonding (Mittal 1977). For salt sizes ranging between 200-400 $\mu \mathrm{m}$ Flake 1a and $1 \mathrm{~b}$ crystals give lower adhesion than flake 2 and cubic crystals (Niman 2000). Flake 1a crystals had better coating efficiency than dendritic salts and cubic salts (Miller and 
Barringer 2002). It was expected that because dendritic crystals have the highest surface area, dendritic crystals should give the highest adhesion.

There is no difference in size and crystal shape of ES and SF dendritic salt. ES dendritic salt contains sodium silicoaluminate, a moisture absorbing, free flowing anticaking agent (Morton 2005).The addition of anti-caking agents to the salts did not produce a difference in adhesion (Figure 4.6).

As concluded previously smaller size crystals give better adhesion than larger size crystals (Figure 4.6). Smaller cubic and flake crystals gave better adhesion than larger cubic and flake crystals. This was because small crystals had greater surface area and stronger van der Waals forces per unit than larger crystals. Miller and Barringer (2002) found that smaller particles have better coating efficiencies than large particles of the same shape. Niman (2000) found that for crystals smaller than $200 \mu \mathrm{m}$, flake 1a, flake 2, dendritic, and cubic crystals had similar adhesion. 


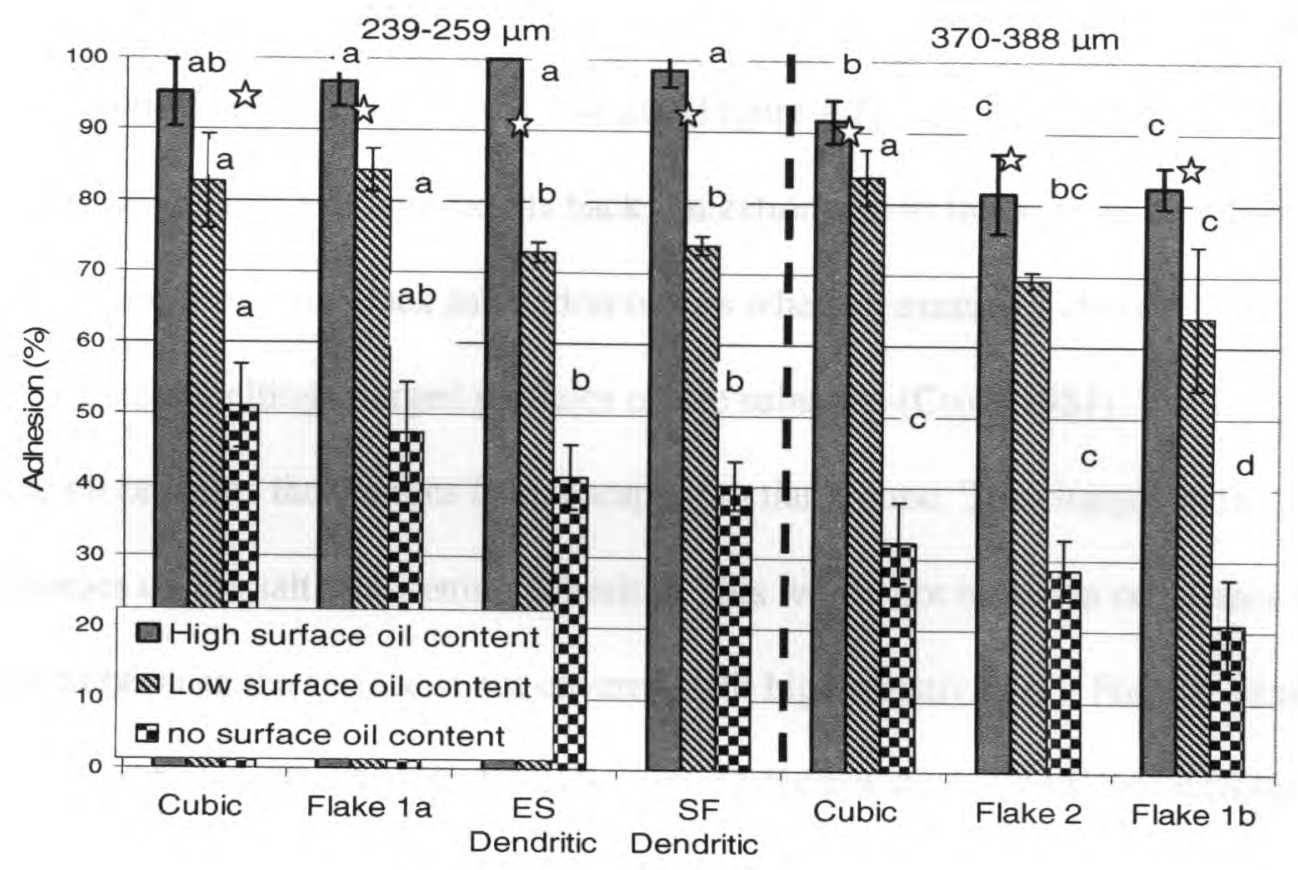

Figure 4.6: Effect of salt shape on adhesion. Stars indicate significant difference between High, Low, and No surface oil content chips. Letters indicate significant difference between samples of the same surface oil content.

\subsection{Electrostatic coating}

\subsubsection{Electrostatic coating and adhesion}

For high and low surface oil chips electrostatic coating did not change adhesion of small salts (Figure 4.7). For small salts less than $260 \mu \mathrm{m}$ nonelectrostatic adhesion was already high at approximately $95 \%$ and it was not expected that using electrostatic coating could further improve adhesion. On oily products such as potato chips electrostatic and nonelectrostatic coating do not show significant differences in adhesion (Halim and Barringer 2007). 
For high and low surface oil chips electrostatic coating significantly decreased adhesion of large salts, 290 and $388 \mu \mathrm{m}$ (Figure 4.7).One possible explanation for the decrease of large salt adhesion is back ionization due to the high resistivity of oil on the surface of the chips. Back ionization occurs when an excess of charge builds up on the substrate, repelling charged particles on the substrate (Cross 1981). The high resistivity of the oil prevents the charges from escaping to the ground. The charges in the oil repel the charges on the salt, weakening adhesion. This would not occur on no surface oil content chips because the surface is not covered with high resistivity oil. For salt sizes above 200 $\mu \mathrm{m}$ electrostatic and nonelectrostatic coating did not show significant differences in adhesion (Halim and Barringer 2007).

For chips with no surface oil electrostatic coating improved adhesion of small salts. It was expected that smaller particles should show greater improvement with electrostatic coating than larger particles because they have a higher charge to mass ratio. Mayr and Barringer (2006) find that transfer efficiency and adhesion of particles $13-80$ $\mu \mathrm{m}$ in size were not significantly different.

For chips with no surface oil large salt did not show improvement in adhesion with electrostatic coating. For salt sizes above $200 \mu \mathrm{m}$ electrostatic and nonelectrostatic coating did not show significant differences in adhesion (Halim and Barringer 2007).

A higher charge to mass ratio results in strong electrostatic adhesion to the substrate. Many studies have shown improvement in adhesion of powders during 
electrostatic coating compared to nonelectrostatic coating (Mayr and Barringer 2006; Halim and Barringer 2007; Setyo and Barringer submitted). Electrostatic coating produces higher transfer efficiency than nonelectrostatic coating (Miller and Barringer 2002; Sumawi and Barringer 2005; Halim and Barringer 2007; Setyo and Barringer submitted). Dustiness decreases with electrostatic coating as particles have high adhesion to the substrate (Ricks and Barringer 2002).

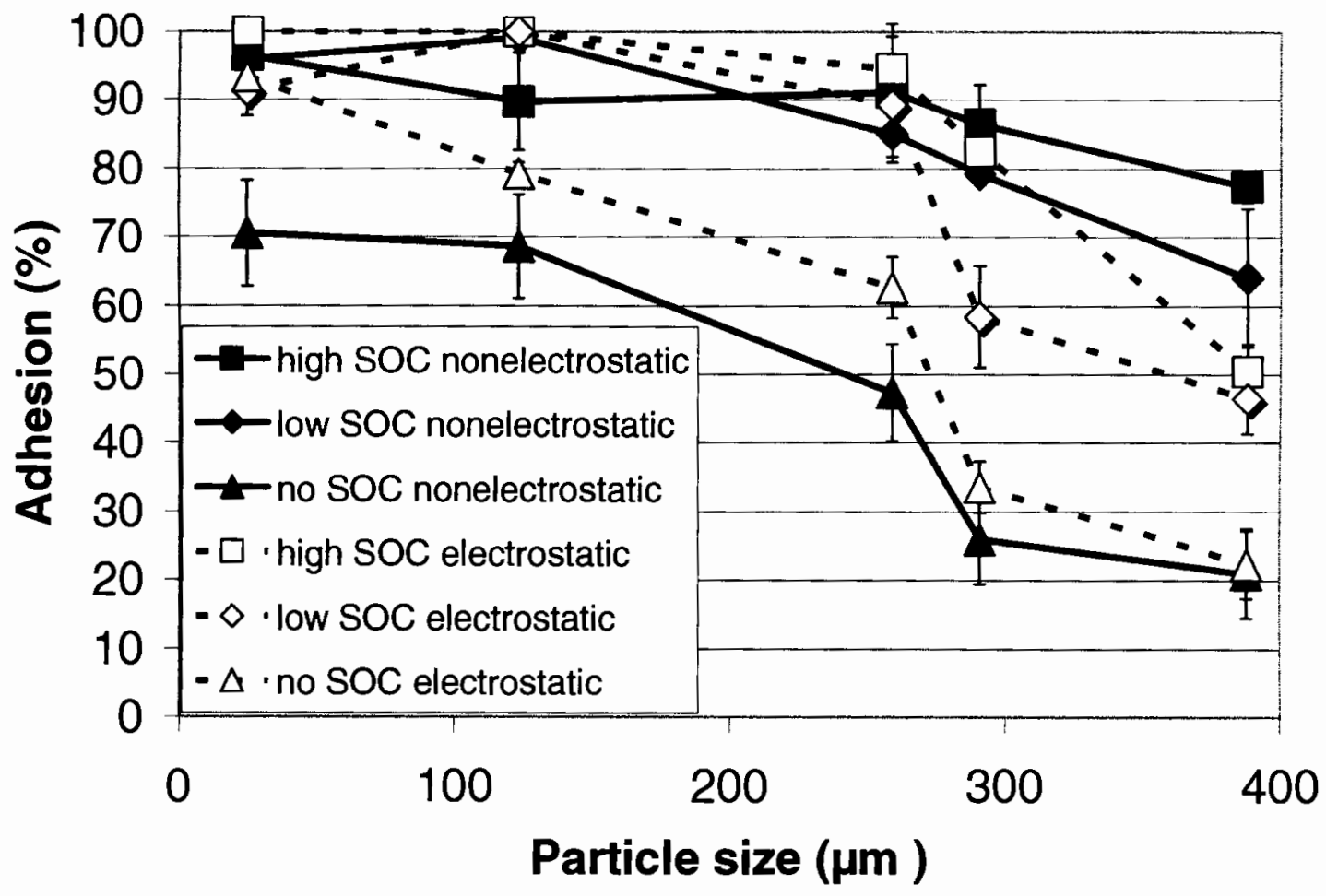

Figure 4.7: Electrostatic and nonelectrostatic adhesion for different salt sizes and surface oil content chips (SOC) 


\section{CHAPTER 5}

\section{CONCLUSIONS}

Surface oil is the most important factor for adhesion. High surface oil content leads to strong capillary forces which dominate over van der Waals and electrostatic forces. Therefore on high surface oil potato chips, there was no effect on adhesion of delayed coating, increased chip temperature, different oil composition, different salt shape and the use of electrostatic coating of small size salts.

Delaying coating reduced adhesion for chips with low surface oil content, as surface oil was absorbed inside the chip. Increasing chip temperature produced higher adhesion values for low and no surface oil chips because surface oil content increased.

Salt size is the second most important factor for adhesion. Smaller size salts have better adherence than larger salt because of stronger van der Waals forces per unit of mass. Smaller size salts gave better adhesion than larger salts of the same shape.

Electrostatic coating improves adhesion of small particles. On no surface oil chips electrostatic coating improved adhesion of small salts due to high charge to mass ratio of smaller salts. On chips with high and low surface oil content, electrostatic coating decreased adhesion of large salts due to high resistivity of oily potato chips. Adhesion of small salts on high and low surface oil chips did not improve with electrostatic coating. 
Adhesion of large salts on no surface oil chips did not improve with electrostatic coating.

Salt shape had little effect on adhesion. Cubic shape salts adhered better than flake and dendritic salts on no surface oil chips. 


\section{LIST OF REFERENCES}


Berard V, Lesniewska E, Andres C, Pertuy D, Laroche C, Pourcelot Y. 2002. Dry powder Inhaler: influence of humidity on topology and adhesion studied by AFM. International $J$ Pharm 232(1-2): 213-224.

Beristain CI, Gracia HS, Vernon-Carter J. 2001. Spray dried encapsulation of cardamom (Elettaria cadamomum) essential oil with mesquite (Prosopis juliflora) gum. Lebensm Wiss Technol 34(6): 398-401

Berry D. 2003. Chip Celebration. Food Product Design 12(5): 33-34,37,40,42,45$50,52,54$.

Biehl HL, Barringer SA. 2004. Comparison of the effect of powder properties on coating transfer efficiency and dustiness in two non-electrostatic and electrostatic systems. Innov Food Sci Emerg Technol 5(2):191-1998.

Bouchon P, Aguilera JM, Pyle DL. 2003. Structure oil-absorption relationships during deep-fat frying. J Food Sci 68(9): 2711-2716.

Bowling AR. 1988. A theoretical review of particle adhesion. In: Mittal KL, editor. Particles on Surfaces. Vol. 1: Detection, Adhesion and Removal. New York: Plenum Press. p129-142.

Brake NC, Fennema OR. 1993. Edible coatings to inhibit lipid migration in a confectionery Product. J. Food Sci 58(6): 1422-1425.

Brown TL, LeMay EH, Bursten BE. 2000. Intermolecular Forces, Liquids, and Solids. In: Challice J, editor. Chemistry the Central Science. $8^{\text {th }}$ Ed. New Jersey: Prentice-Hall. p396.

Bunger A, Moyano P, Rioseco V. 2003. NaCl soaking treatment for improving the quality of french fried potatoes. Food Research Int 36(2):161-166.

CalifanoA, Calveco A. 1987. Adjustment of surface concentration of reducing sugars before frying of potato strips. J. Food Process. Preserv. 12(1): 1-9.

Cross JA. 1981. Electrostatic powder coating. Chem Brit, 17(1): 24-26.

Cross JA. 1975. Adhesion of electrostatic powder coatings. In: Blythe AR, editor. Static electrification. Inst Phys Conf Ser No 27: 202-212. 
Czopek AT. 2003. Changes of pectic substances concentration in potatoes and french fries and the effect of these substances on the texture of the final product. Nahrung Food 37(4): 228-231.

Dunford N. Food Technology Fact Sheet. 2003. Deep fat frying basics for food services. Food and Agriculture Products Research and Technology Center. Oklahoma State University. Available from: www.fapc.okstate.edu/factsheets/deepfatfrying.pdf 02-23-07

Enggalhardjo M, Narsimhan G. 2005. Adhesion of dry seasoning particles onto tortilla chip. J Food Sci 70(3): E215-E222.

Fizman SM, Salvador A. 2003. Recent development in coating batter. Trends in Food Sci and Technol 14(10): 399-407.

Goni I, Bravo L, Larraui JA, Calixto FS. 1997. Resistant starch in potatoes deep fried in olive oil. J Food Chem 59(2): 269-272.

Gould WA.1994. Snack Food Manufacturing and Quality Assurance Manual. Snack Food Association. Arlington VA. p51

Halim F, Barringer SA. 2007. Electrostatic adhesion in food. J Electrostat 65(3):168-173.

Henry WF, Katz MH. 1969. New dimensions relating to the textural quality of semi-solid foods and ingredient systems. Food Tech 23(822): 114-117.

Feliz DJ, Proctor A, Monsoor MA, Eason RL. 2005. The effects of damaged kernel caused by combine harvester settings on milled rice free fatty acid levels. J Food Sci 70(6): C376-C379.

Finney JF, Buffo R, Reineccius GA. 2002. Effects of type of atomization and processing temperature on the physical properties and stability of spray dried flavors. J Food Eng 67(2): 1108-1113.

Jimenez M, Garcia HS, Beristain CI. 2004. Spray-drying microencapsulation and oxidative stability of conjugated linoleic acid. Eur Food Res Technol 219(6): 588-592.

Jonnalagada PR, Bhat R, Sudershan RV, Naidu AN, 2001. Suitability in chemical parameters of setting quality standards for deep-fried snacks. Food Quality Pref 12(4): 223-228. 
Kawas ML, Moreira RG. 2001. Effect of degree of starch gelatinization on quality attributes of fried tortilla chips. J Food Eng 66(2): 300-306.

Kendall K, Stainton C. 2001.Adhesion and aggregation of fine particles.Powder Technol (121): 223-229.

Kuntz LA. 1994. The many benefits of salt. Food Product Design. 3(10): 48-61.

Lam KK, Newton JM. 1991. Investigation of applied compression on the adhesion of powders to a substrate surface. Powder Technol (6): 167-175.

Mayr MB, Barringer SA. 2006. Corona compared with triboelectric charging for electrostatic powder coating. J Food Sci 71(4): $171-177$.

Melton SL, Trigiano MK, Penefield MP, Yang R. 1993. Potato chips fried in canola and/or cottonseed oil maintain high quality. J Food Sci 58(5):1079-83.

Michalski MC, Desobry S, Hardy J. 1997. Food materials adhesion: A review. Critical review Food Sci Nutr. 37(7): 591 - 619.

Michalski MC, Desobry S, Hardy J. 1998. Adhesion of edible oils and food emulsions to rough surfaces. Lebensm Wiss Technol 31(5): 495-502.

Miller MJ, Barringer SA. 2002. Effect of sodium chloride particle size and shape on nonelectrostatic and electrostatic coating of popcorn. J Food Sci 67(1): 198-201.

Mittal KL. 1977. The role of the interface in adhesion phenomena. Polymer Eng Sci 17(7): 467-473.

Moreira R, Sun X, Chen Y. 1997. Factors affecting oil uptake in tortilla chips in deep-fat frying. J Food Eng 31(4): 485-498.

Morton Salt Company. 1997. Chicago, IL. The unique physical properties of Morton star flake dendritic salt.

Morton Salt Company. 2004. Chicago, IL. Top flake salt product data sheet.

Morton Salt Company. 2005. Chicago, IL. Star flake dendritic and dendritic ES salt product data sheet. 
Noureddini H, Teoh BC, Clements DL.1992. Densities of vegetable oils and fatty acids. J of Am Oil Chem Soc. 69(12):1184-1188.

Niamnuy C, Devahastin S. 2005 Drying kinetics and quality of coconut dried in a fluidized bed dryer. J Food Eng 66(3): 267-271.

Niman CE. 2000. In search of the perfect salt for topping snack foods. Cereal Foods World 45(10): 466-469.

Padukka I, Bhandari B, Arcy DB.2 000. Evaluation of various extraction methods of encapsulated oil from $b$-cyclodextrin-lemon oil complex powder. J Food Comp and Anal. 13(1): 59-70.

Park JW, Testin RF, Vergano PJ, Park HJ, Weller CL.1996. Application of laminated edible films to potato chip packaging. J Food Sci 60(4): 776-778.

Pedreschi E, Aguilera J M, Pyle L. 2001.Textural characterization and kinetics of potato strips during frying. J Food Sci 66(2): 314-318.

Pedreschi F, Kaack K. 2004.Reduction of acrylamide formation in potato slices during frying. Lebensm Wiss Technol 37(6):679-685.

Pedreschi F, Moyano P. 2005a. Effect of predrying on texture and oil uptake of potato chips. Lebensm Wiss Technol 38(6):599-604.

Pedreschi F, Moyano P. 2005b. Oil uptake and texture development in fried potato slices J. Food Eng 70(6):557-563.

Pedreschi F, Moyano P. 2006. Kinetics of oil uptake during frying of potato slices: Effect of pre-treatments. Lebensm Wiss Technol 39(3):285-291.

Pinthus EJ, Weinberg P, and Saguy IS.1995. Oil uptake in deep fat frying as affected by porosity. J Food Sci 60(4): 767-769.

Ranade MB. 1987. Adhesion and removal of fine particles on surfaces. Aerosol Sci Technol 7(2): 161-176

Rao SN, Barringer SA. 2006.Calcification of diced tomatoes by liquid dipping versus electrostatic powder coating. J Food Process and Pres (30):71-78. 
Ricks NP, Barringer SA, Fitzpatrick JJ. 2002. Food powder characteristics important to nonelectrostatic and electrostatic coating and dustiness. J Food Sci 67 (6): 2256-2263.

Setyo D, Barringer SA. Effect of pH and electrostatic polarity on food powder coating transfer efficiency and adhesion. J Food Sci submitted.

Singh U, Seetha R. 1993. Oil absorption and sensory properties of a snack food from chickpeas Genotypes. J Food Sci 58(4): 853-855.

Soottitantawat A, Bigeard F, Yoshii H, Furuta T, Ohkawara M, Linko P. 2005. Influence of emulsion and powder size on the stability of encapsulated D-limonene by spray drying. Innov Food Sci Emerg Technol 6(1): 107-114.

Strietelmeier DM. 1988. Salt grade selection for baking application. In: Stitley J. Technical Bulletin Salt, Selection, Use. Kansas: American Institute of Baking p.1-10.

Sumawi H, Barringer SA. 2005. Positive vs. negative electrostatic coating using food powders. J Electrostat 63(6-10): 815-821.

Takenaka N, Ogata K, Yabe T, Yamauchi R, Kato K. 2006. Effect of oil and sugar contents on the surface of dehulled-roasted sesame seeds on adhesion between the seeds. J Food Sci 71(6): E303-E307.

Tsai LS, Huxsoll CC, Robertson G. 2001. Prevention of potato spoilage during storage by cholorine dioxide. J Food Sci 66(3): 472-476.

Turchiuli C, Fuchs M, Bohin M, Cuvelier ME, ordonnaud C, Pyrrat Maillard MN, Dumoulin E. 2005. Oil encapsulation by spray drying and fluidized bed agglomeration. Innov Food Sci Emerg Technol 6(1): 29-35.

Warner K, Gupta M. 2005. Potato chip quality and frying oil stability of high oleic acid soybean oil. J Food Sci 70(6): 395-400.

Yousuf S, Barringer SA. Modeling nonelectrostatic and electrostatic powder coating. J Food Eng submitted. 
APPENDIX A

\section{ADHESION DATA \& FIGURES}




\begin{tabular}{|c|c|c|c|}
\hline $\begin{array}{c}\text { Commercial } \\
\text { Name }\end{array}$ & Shape & Anticaking agent & Size ( $\mu \mathrm{m})$ \\
\hline $\begin{array}{c}\text { Cargill Alberger } \\
\text { Fine Flake }\end{array}$ & Flake & None & 259 \\
\hline $\begin{array}{c}\text { Morton ES } \\
\text { Dendritic }\end{array}$ & Dendritic & $\begin{array}{c}\text { tricalcium } \\
\text { phosphate (TCP) }\end{array}$ & 251 \\
\hline $\begin{array}{c}\text { Morton SF } \\
\text { Dendritic }\end{array}$ & Dendritic & None & 239 \\
\hline $\begin{array}{c}\text { Morton TFC 999 } \\
\text { Fine }\end{array}$ & Cubic & yellow Prussiate of & Soda \\
(YPS) & 247 \\
\hline $\begin{array}{c}\text { Morton Purex Fine } \\
\text { Prepared }\end{array}$ & Cubic & $\begin{array}{c}\text { tricalcium } \\
\text { phosphate }\end{array}$ & 370 \\
\hline $\begin{array}{c}\text { Morton Top Flake } \\
\text { Fine }\end{array}$ & Flake & None & 375 \\
\hline $\begin{array}{c}\text { Cargill Alberger } \\
\text { Coarse }\end{array}$ & Flake & None & 388 \\
\hline
\end{tabular}

Table A.1: Sait crystal shapes and their attributes. 


\begin{tabular}{|c|c|c|c|c|c|c|}
\hline $\begin{array}{c}\text { Temperature } \\
{ }^{\circ} \text { C }\end{array}$ & $\begin{array}{c}\text { Adhesion } \\
\text { High SOC } \\
\text { Chips (\%) }\end{array}$ & $\begin{array}{c}\text { Standard } \\
\text { deviation } \\
\text { High SOC } \\
\text { chips }\end{array}$ & $\begin{array}{c}\text { Adhesion } \\
\text { Low SOC } \\
\text { Chip (\%) }\end{array}$ & $\begin{array}{c}\text { Standard } \\
\text { deviation } \\
\text { Low } \\
\text { SOC chips }\end{array}$ & $\begin{array}{c}\text { Adhesion } \\
\text { No SOC } \\
\text { Chips (\%) }\end{array}$ & $\begin{array}{c}\text { Standard } \\
\text { deviation } \\
\text { No SOC } \\
\text { chips }\end{array}$ \\
\hline $\mathbf{2 2}$ & 95.27 & 2.72 & 75.99 & 1.72 & 47.39 & 7.09 \\
\hline $\mathbf{5 0}$ & 97.36 & 1.92 & 90.91 & 2.93 & 74.51 & 5.00 \\
\hline $\mathbf{7 0}$ & 98.89 & 2.24 & 93.93 & 1.99 & 84.29 & 6.30 \\
\hline $\mathbf{9 3}$ & 98.59 & 1.28 & 90.23 & 3.02 & 80.93 & 5.26 \\
\hline $\mathbf{1 4 9}$ & 99.61 & 0.67 & 82.08 & 3.21 & 75.54 & 0.48 \\
\hline $\mathbf{2 0 4}$ & 99.11 & 0.78 & 85.36 & 1.63 & 76.55 & 2.89 \\
\hline
\end{tabular}

Table A.2: Adhesion values for high, low, and no surface oil content chips at different temperatures.

\begin{tabular}{|c|c|c|c|c|c|c|}
\hline $\begin{array}{c}\text { Temperature } \\
\mathbf{~}^{\mathbf{C}}\end{array}$ & $\begin{array}{c}\text { Average } \\
\text { High SOC } \\
\left(\mathbf{m g} / \mathbf{c m}^{\mathbf{2}}\right)\end{array}$ & $\begin{array}{c}\text { Standard } \\
\text { deviation } \\
\text { High SOC } \\
\left(\mathbf{m g} / \mathbf{c m}^{2}\right)\end{array}$ & $\begin{array}{c}\text { Average } \\
\text { Low SOC } \\
\left(\mathbf{m g} / \mathbf{c m}^{2}\right)\end{array}$ & $\begin{array}{c}\text { Standard } \\
\text { deviation } \\
\text { Low SOC } \\
\left(\mathbf{m g} / \mathbf{c m}^{2}\right)\end{array}$ & $\begin{array}{c}\text { Average } \\
\text { No SOC } \\
\left(\mathbf{m g} / \mathbf{c m}^{2}\right)\end{array}$ & $\begin{array}{c}\text { Standard } \\
\text { deviation No } \\
\text { SOC }\left(\mathbf{m g} / \mathbf{c m}^{2}\right)\end{array}$ \\
\hline $\mathbf{2 2}$ & 1.680 & 0.294 & 1.679 & 0.296 & 0.000 & 0.000 \\
\hline $\mathbf{5 0}$ & 2.519 & 0.000 & 2.325 & 0.274 & 0.775 & 0.000 \\
\hline $\mathbf{7 0}$ & 3.068 & 0.676 & 2.422 & 0.296 & 1.114 & 0.331 \\
\hline $\mathbf{9 3}$ & 3.875 & 0.274 & 2.713 & 0.548 & 0.872 & 0.137 \\
\hline $\mathbf{1 4 9}$ & 3.326 & 0.676 & 2.842 & 0.567 & 0.436 & 0.331 \\
\hline $\mathbf{2 0 4}$ & 3.197 & 0.137 & 2.519 & 0.274 & 0.194 & 0.274 \\
\hline
\end{tabular}

Table A.3: Surface oil content measurements at different temperatures. 


\begin{tabular}{|l|c|}
\hline Total oil content of chips at $22^{\circ} \mathbf{C}$ & $77.14 \mathrm{mg}$ \\
\hline Surface oil content at $22^{\circ} \mathbf{C}$ & $10.83 \mathrm{mg}$ \\
\hline Center oil & $0.06631 \mathrm{~g}$ \\
\hline Volume center oil at $\mathbf{2 2}{ }^{\circ} \mathbf{C}$ & $0.07287 \mathrm{ml}$ \\
\hline Volume center oil at $\mathbf{1 0 0}{ }^{\circ} \mathbf{C}$ & $0.07622 \mathrm{ml}$ \\
\hline Oil that goes to the surface & $0.003350 \mathrm{ml}$ \\
\hline weight of new oil on surface & $2.915 \mathrm{ml}$ \\
\hline measure SOC at $\mathbf{1 0 0 ~ C}$ & $17.50 \mathrm{mg}$ \\
\hline calculated SOC at $\mathbf{1 0 0}$ & $13.74 \mathrm{mg}$ \\
\hline
\end{tabular}

Table A.4: Comparison of measured surface oil and calculated surface oil. Density of soybean oil at 23.9 ${ }^{\circ} \mathrm{C}=0.91 \mathrm{~g} / \mathrm{ml}$. Density of soybean oil at $100{ }^{\circ} \mathrm{C}=0.87 \mathrm{~g} / \mathrm{ml}$. Values adapted from Noureddini and others (1992).

\begin{tabular}{|l|c|c|}
\hline \multicolumn{1}{|c|}{ SAMPLE } & Adhesion \% & $\begin{array}{c}\text { Standard deviation } \\
(\%)\end{array}$ \\
\hline High SOC Chips & 94.04 & 4.08 \\
\hline High SOC 1-day old chips & 95.59 & 4.68 \\
\hline High SOC 1-month old chips & 95.74 & 1.18 \\
\hline Low SOC Chips & 84.97 & 3.27 \\
\hline Low SOC 1-day old chips & 77.43 & 2.33 \\
\hline Low SOC 1-month old chips & 76.25 & 6.44 \\
\hline No SOC chips & 47.39 & 7.09 \\
\hline No SOC 1-day old & 45.43 & 6.21 \\
\hline No SOC 1-month old chips & 67.46 & 5.41 \\
\hline
\end{tabular}

Table A.5: Adhesion values after delaying and coating 


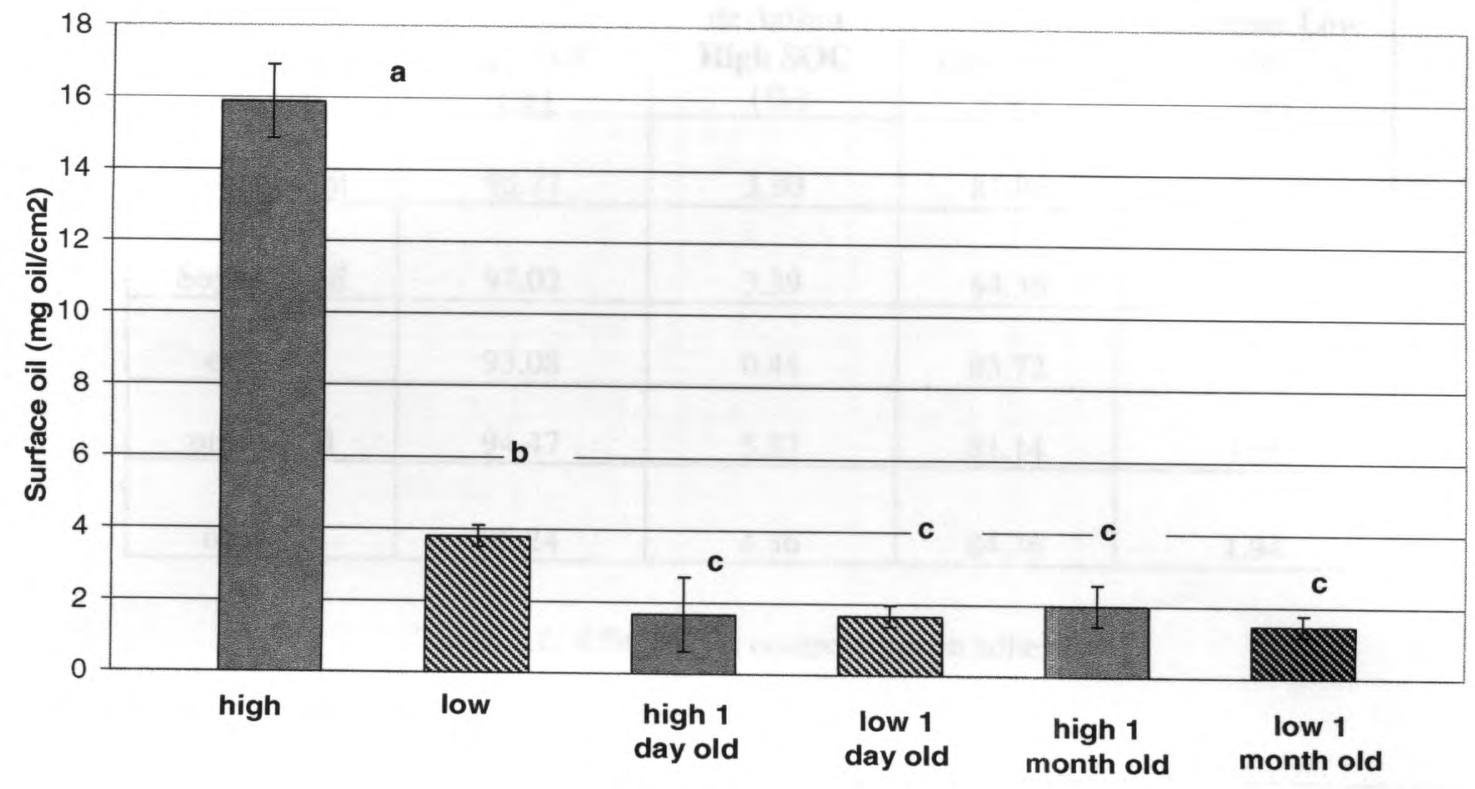

Figure A.1: Surface oil content measurement of chips after 1 day. Letters indicate significant difference between samples of the same surface oil content (SOC) 


\begin{tabular}{|c|c|c|c|c|}
\hline Sample & $\begin{array}{c}\text { Adhesion } \\
\text { High SOC } \\
(\boldsymbol{\%})\end{array}$ & $\begin{array}{c}\text { Standard } \\
\text { deviation } \\
\text { High SOC } \\
(\boldsymbol{\%})\end{array}$ & $\begin{array}{c}\text { Adhesion } \\
\text { Low SOC } \\
(\%)\end{array}$ & $\begin{array}{c}\text { Standard } \\
\text { deviation Low } \\
\text { SOC } \\
(\%)\end{array}$ \\
\hline Coconut oil & 95.77 & 3.90 & 81.96 & 7.48 \\
\hline Soybean oil & 97.02 & 3.39 & 84.36 & 3.02 \\
\hline corn oil & 93.08 & 0.48 & 83.72 & 2.85 \\
\hline peanut oil & 94.47 & 5.37 & 81.14 & 3.06 \\
\hline & & 4.36 & 84.36 & 1.94 \\
\hline
\end{tabular}

Table A.6: Effect of oil composition on adhesion

\begin{tabular}{|c|c|c|c|c|c|c|}
\hline $\begin{array}{c}\text { Size } \\
(\mu \mathrm{m})\end{array}$ & $\begin{array}{c}\text { Adhesion } \\
\text { High SOC }\end{array}$ & $\begin{array}{c}\text { Standard } \\
\text { deviation } \\
\text { High SOC }\end{array}$ & $\begin{array}{c}\text { Adhesion } \\
\text { Low SOC }\end{array}$ & $\begin{array}{c}\text { Standard } \\
\text { deviation } \\
\text { Low SOC }\end{array}$ & $\begin{array}{c}\text { Adhesion } \\
\text { No SOC }\end{array}$ & $\begin{array}{c}\text { Standard } \\
\text { deviation } \\
\text { No SOC }\end{array}$ \\
\hline $\mathbf{2 5}$ & 96.33 & 3.31 & 95.93 & 4.62 & 70.57 & 7.68 \\
\hline $\mathbf{1 2 3}$ & 89.73 & 7.16 & 99.12 & 2.15 & 68.68 & 7.54 \\
\hline $\mathbf{2 5 9}$ & 91.11 & 10.18 & 84.36 & 3.02 & 47.39 & 7.09 \\
\hline $\mathbf{2 9 1}$ & 86.47 & 5.79 & 79.25 & 0.72 & & 25.97 \\
\hline $\mathbf{3 8 8}$ & 82.51 & 4.04 & 64.16 & 10.04 & 21.00 & 6.41 \\
\hline
\end{tabular}

Table A.7: Effect of salt size on adhesion 


\begin{tabular}{|c|c|c|c|c|c|c|c|}
\hline $\begin{array}{c}\text { Commercial } \\
\text { Name }\end{array}$ & Sample & $\begin{array}{c}\text { Adhesion } \\
\text { High } \\
\text { SOC } \\
(\%)\end{array}$ & $\begin{array}{c}\text { Standard } \\
\text { deviation } \\
\text { High } \\
\text { SOC }(\%)\end{array}$ & $\begin{array}{c}\text { Adhesion } \\
\text { Low } \\
\text { SOC } \\
(\%)\end{array}$ & $\begin{array}{c}\text { Standard } \\
\text { deviation } \\
\text { Low SOC } \\
(\%)\end{array}$ & $\begin{array}{c}\text { Adhesion } \\
\text { No } \\
\text { SOC } \\
(\%)\end{array}$ & $\begin{array}{c}\text { Standard } \\
\text { deviation } \\
\text { No SOC } \\
(\%)\end{array}$ \\
\hline $\begin{array}{c}\text { Purex Fine } \\
\text { Prepared }\end{array}$ & $\begin{array}{c}\text { Cubic } \\
\text { YPS }\end{array}$ & 95.07 & 4.77 & 82.63 & 6.65 & 51.02 & 5.97 \\
\hline $\begin{array}{c}\text { Alberger } \\
\text { Fine Flake }\end{array}$ & Flake 1a & 96.7 & 3.33 & 84.36 & 3.02 & 47.39 & 7.09 \\
\hline ES Dendritic & Dendritic & 100 & 0 & 72.88 & 1.37 & 41.16 & 4.57 \\
\hline SF Dendritic & $\begin{array}{c}\text { Dendritic } \\
\text { TCP }\end{array}$ & 98.58 & 2.46 & 73.93 & 1.29 & 40.13 & 3.37 \\
\hline TFC 999 Fine & $\begin{array}{c}\text { Cubic } \\
\text { TCP }\end{array}$ & 91.51 & 2.97 & 83.68 & 3.97 & 32.38 & 5.65 \\
\hline $\begin{array}{c}\text { Top Flake } \\
\text { Fine }\end{array}$ & Flake 2 & 81.54 & 5.67 & 69.44 & 1.17 & 28.64 & 4.26 \\
\hline $\begin{array}{c}\text { Alberger } \\
\text { Coarse Flake }\end{array}$ & Flake 1b & 82.51 & 2.92 & 64.16 & 10.04 & 21.00 & 6.50 \\
\hline
\end{tabular}

Table A.8: Effect of particle shape on adhesion 


\begin{tabular}{|c|c|c|c|c|c|}
\hline Size & Sample & Adhesion \% NE & SD NE & Adhesion \% ES & SD ES \\
\hline \multirow[t]{3}{*}{24.75} & High & 96.47 & 2.72 & 100.00 & 0.00 \\
\hline & Low & 95.93 & 4.62 & 91.33 & 3.60 \\
\hline & No & 70.57 & 7.68 & 93.33 & 5.77 \\
\hline \multirow[t]{3}{*}{123.31} & High & 89.73 & 7.16 & 100.00 & 0.00 \\
\hline & Low & 99.12 & 2.15 & 100.00 & 0.00 \\
\hline & No & 68.68 & 7.54 & 79.23 & 1.61 \\
\hline \multirow[t]{3}{*}{258.91} & High & 91.11 & 10.18 & 94.50 & 4.84 \\
\hline & Low & 84.97 & 3.27 & 89.27 & 1.49 \\
\hline & No & 47.39 & 7.09 & 62.73 & 4.46 \\
\hline \multirow[t]{3}{*}{290.60} & High & 86.47 & 5.79 & 82.51 & 2.22 \\
\hline & Low & 79.25 & 0.72 & 58.46 & 7.41 \\
\hline & No & 25.97 & 6.41 & 33.61 & 3.76 \\
\hline \multirow[t]{3}{*}{388.03} & High & 77.40 & 2.26 & 50.54 & 3.96 \\
\hline & Low & 64.16 & 10.04 & 46.46 & 5.15 \\
\hline & No & 21.00 & 6.50 & 22.30 & 4.94 \\
\hline
\end{tabular}

Table A.9: Effect of electrostatic coating compared with nonelectrostatic coating. NE stands for non electrostatic coating. ES stands for electrostatic coating. SD stands for standard deviation. 